San Jose State University

SJSU ScholarWorks

Master's Theses

Master's Theses and Graduate Research

Fall 2010

\title{
Comparative Study of the Practice of Product Placement in Bollywood and Hollywood Movies
}

Shruti Vinayak Gokhale

San Jose State University

Follow this and additional works at: https://scholarworks.sjsu.edu/etd_theses

Part of the Mass Communication Commons

\section{Recommended Citation}

Gokhale, Shruti Vinayak, "Comparative Study of the Practice of Product Placement in Bollywood and Hollywood Movies" (2010). Master's Theses. 3860.

DOI: https://doi.org/10.31979/etd.ay5m-zh5z

https://scholarworks.sjsu.edu/etd_theses/3860

This Thesis is brought to you for free and open access by the Master's Theses and Graduate Research at SJSU ScholarWorks. It has been accepted for inclusion in Master's Theses by an authorized administrator of SJSU ScholarWorks. For more information, please contact scholarworks@sjsu.edu. 


\title{
COMPARATIVE STUDY OF THE PRACTICE OF PRODUCT PLACEMENT IN BOLLYWOOD AND HOLLYWOOD MOVIES
}

\author{
A Thesis \\ Presented to \\ The Faculty of the School of Journalism and Mass Communications \\ San José State University \\ In Partial Fulfillment \\ of the Requirements for the Degree \\ Master of Science \\ by \\ Shruti Gokhale \\ December 2010
}


(C) 2010

Shruti V. Gokhale

ALL RIGHTS RESERVED 
The Designated Thesis Committee Approves the Thesis Titled

\title{
COMPARATIVE STUDY OF THE PRACTICE OF PRODUCT PLACEMENT IN BOLLYWOOD AND HOLLYWOOD MOVIES
}

\author{
By Shruti Gokhale \\ APPROVED FOR THE SCHOOL OF JOURNALISM AND MASS \\ COMMUNICATIONS
}

SAN JOSÉ STATE UNIVERSITY

December 2010

Dr. Diana Stover

School of Journalism and Mass Communications

Prof. Tim Hendrick

School of Journalism and Mass Communications

Dr. Arvinder Loomba

College of Business 


\section{ABSTRACT \\ COMPARATIVE STUDY OF THE PRACTICE OF PRODUCT PLACEMENT IN BOLLYWOOD AND HOLLYWOOD MOVIES \\ By Shruti Gokhale}

Product placement, or placing brands in movies, is a widely recognized practice that dates from the 1980s. This study is a content analysis of product placement in 15 Bollywood and 15 Hollywood movies from 2005 to 2009.

Statistical tests showed that there were a significantly higher number of product placements in Hollywood movies that were integrated into the storylines, verbally referred to by characters in the movies, appropriate to the movie scenes, and containing implied endorsements by the actors than product placements in Bollywood movies. However, in terms of duration of the time that brands were onscreen, product placements in Bollywood movies in 2006 and 2007 were significantly greater than in Hollywood movies.

The results also showed many similarities between the movie industries in the two countries. Transportation was the most prominent product category followed by electronics in both Bollywood and Hollywood. Brands from both the industries were primarily presented in a positive context and were mainly associated with the primary movie characters. Almost all the products were featured in such a way that their brand names or logos were shown as well their other functional or aesthetic qualities. 


\section{ACKNOWLEDGEMENTS}

I would like to take this opportunity to thank my husband Manas Gopujkar, who made my education at San Jose State University possible and supported me in every way. He believed in me and helped me a lot during this somewhat tiresome process and for this I am evermore grateful.

I would also like to thank all my family members for their encouraging words. Their presence has always been at the back of my mind.

Finally, I would like to thank my advisors - Dr. Diana Stover, Prof. Tim Hendrick, and Dr. Arvinder Loomba. Without their support and guidance, I could not have finished my thesis. I am very grateful for their feedback and assistance. 


\section{TABLE OF CONTENTS}

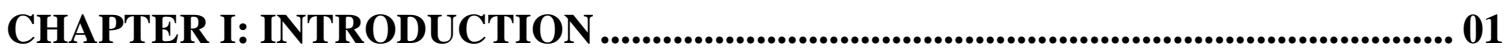

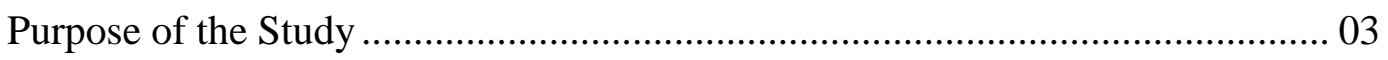

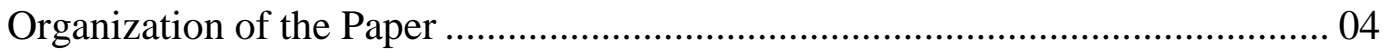

CHAPTER II: REVIEW OF THE LITERATURE ....................................................... 06

Definition and Meaning of Product Placement................................................. 06

The American Film Industry: Hollywood....................................................... 07

Product Placement in Hollywood Cinema......................................................... 10

The History of Indian Cinema and Bollywood................................................. 18

Product Placement in Bollywood Cinema ........................................................ 21

Overview and Analytical Framework........................................................... 24

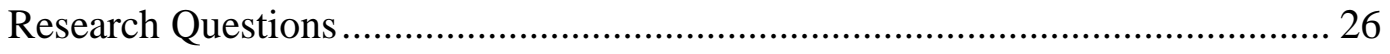

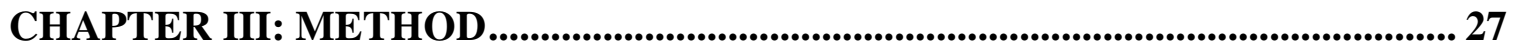

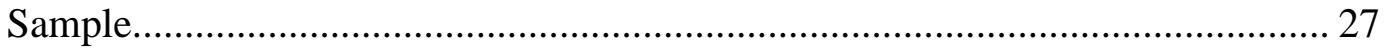

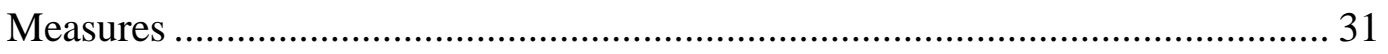

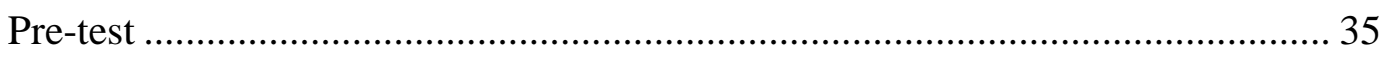

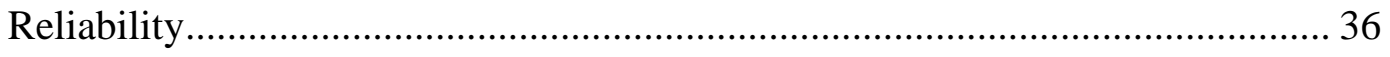




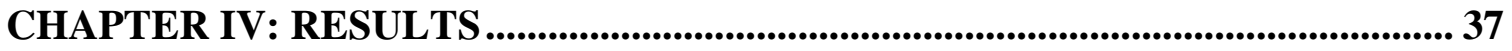

Overview of the Results .................................................37

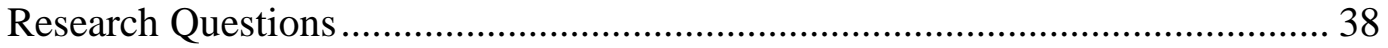

CHAPTER V: CONCLUSION......................................................................................... 63

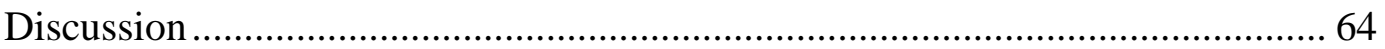

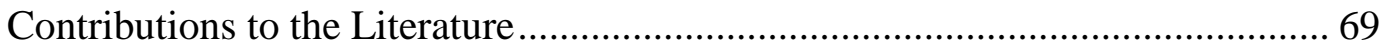

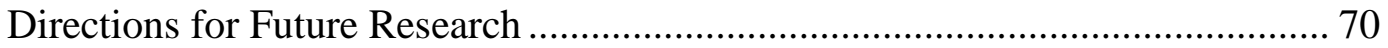

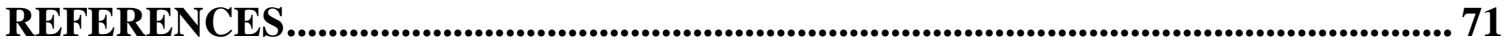

APENDIX A: CODING GUIDE...............................................74 


\section{LIST OF TABLES}

Table 1: List of Bollywood movies included in the sample

Table 2: List of Hollywood movies included in the sample

Table 3: Frequencies of major product categories in Bollywood and Hollywood movies

Table 4: Frequencies of product subcategories in Bollywood and Hollywood movies

Table 5: Duration of combined product placements per year

Table 6: Independent sample t-test for overall duration of product placements

Table 7: Duration of combined brand name appearances per year

Table 8: Independent sample t-test for duration of brand name appearances

Table 9: Frequencies of presentation of product placement for Bollywood and Hollywood brand appearances 
Table 10: Chi Square for integration of product placement into the storyline across film industries

Table 11: Chi-square for appropriateness of placement across film industries

Table 12: Chi-square for implied endorsement across film industries

Table 13: Chi-square for verbal reference across film industries

Table 14: Frequency distribution of the level of product placement 


\section{CHAPTER I}

\section{INTRODUCTION}

Commercialism has been an integral part of all forms of mass media that have been in existence since the nineteenth century. There is no better way to reach the audience than to place a product in the hands of stars, who the audience views with dreamy eyes and who possess an incredible power to influence consumer behavior. The concept of product placement in the movies has been an engaging and exciting research topic for mass communication scholars for many years now. For Hollywood filmmakers and U.S. marketers, the practice of product placement is an established concept. However, it is still a developing practice in the Bollywood cinema-the mainstream Hindi film industry based in Mumbai, India, formerly known as Bombay. This thesis analyzed the practice of product placement in the films produced in Bollywood and Hollywood.

Although the concept of placing a product in a film for payment is relatively new to Bollywood, it is certainly not an unheard of practice. Using celebrities' influence to establish a social trend or fashion can be traced back to Hindi movies from the 1950s. Bollywood has always reflected Indian culture. The mainstream Hindi cinema is usually the result of all the unmistakable Indian specialties such as colorful costumes and sets, exotic locations, and, most important of all, song and dance sequences (Dwyer \& Patel, 2002). During the past 96 years, numerous technicians, directors, actors, and actresses have come to the Hindi cinema industry from all corners of India. They have brought with them their regional culture and languages, which have blended perfectly to create the Bollywood cinema that exists today. Bollywood movies not only reflect the day-to- 
day life of ordinary Indians, but, as in America, have also become a part of Indian life. As a result, the Indian audience, instead of thinking of a movie as a make-believe phenomenon, can relate to it and become emotionally involved with the actors working in it. They look to Bollywood to tell them how to dress fashionably, how to talk impressively, and how to behave in social settings (Dwyer \& Patel, 2002). For a long time, screen stars have served as idols for Indian audiences. As a result, Bollywood has become a huge marketplace for promoting goods and services (Kripalani, 2006).

There were a few Hindi films before the 1990s that featured identifiable brands in some of the scenes. However, those brand placements were on a very limited scale and generally went unnoticed by the audience. The first highly noticed product placement was Coca-Cola in the box office hit movie Taal (The Rhythm) in 1999 (Kripalani, 2006). Coca-Cola appears more than once in Taal as a prominent drink accompanying the stars in various emotional situations such as love, friendship, and nostalgia (Kripalani, 2006). Since then, product placement has become common in Hindi films.

As for Hollywood, it has come a long way from the nickelodeon era of colored advertisement slides appearing between two entertainment reels (Segrave, 2004). Although advertisements have been a part of Hollywood movies for a very long time, public consciousness about the practice of product placement came with the movie E.T., The Extra-Terrestrial (1982). Elliott, a character in the film, lays down Reese's Pieces to invite the alien into his home (Kripalani, 2006; Newell, Salmon, \& Chang, 2006). Since then, the audience has become used to these numerous brand insertions into films. 
Today, product placement is a multimillion dollar industry that satisfies film producers by reducing the cost of production and marketers by boosting sales.

\section{Purpose of the Study}

The purpose of this study is to compare the practice of product placement in Bollywood and Hollywood films from 2005 to 2009, the last 5 years of the decade. The research conducted by Galician and Bourdeau (2004) and Kripalani (2006) was used as the basis of an analytical framework to examine product placement. The study was designed to answer questions such as what were the most prominent brands to appear onscreen in both the film industries; were there any specific patterns in the recent product placement trend among marketers; and was there any specific type of product placement that was most common? It examined the level of product placement, the number of types of products in a film, and the time-duration of each brand appearing onscreen. It also covered the primary association of a brand in the film. Overall, the research focuses on analyzing whether there were any similarities or differences between the product placements in Indian films and American films.

For the analysis, the top three box-office hit movies in the 5-year period from both Bollywood and Hollywood were selected. The movies for this research were box office hits selected from seven movie genres.

The practice of product placement has now existed for more than 100 years in America, and scholars have done research on product placement in American films for several decades. This study, however, is different in three ways. First, it analyzes Bollywood, the Hindi film industry in India. Although several articles in scholarly 
journals have touched on the issue of product placement in Bollywood films, a search of the literature did not find any content analyses. Therefore, this study may be the first of its kind. Second, even though there have been content analyses of Hollywood movies, there have been no reported studies of product placement in movies released between 2005 and 2009. Finally, there have been no comparative studies of product placement in Bollywood and Hollywood.

\section{Organization of the Paper}

In terms of the organization of this thesis, Chapter II provides a review of the relevant literature on understanding the term product placement and a brief history of how Hollywood and Bollywood were developed. It is followed by a history of product placement in Hollywood and Bollywood movies. Chapter II also presents an analytical framework based on previous research.

Chapter III provides a discussion of the method for the research, including the sample of movies, the measures, and the definitions of the measures. Thirty movies-15 from Bollywood and 15 from Hollywood-were included in the sample. A total of 9 elements of product placement were identified to conduct a product-placement analysis in the movies from 2005 to 2009.

The results of the study are discussed in Chapter IV. It provides a detailed analysis of each of the nine product placement elements and includes the statistical tests used to answer the six research questions.

A summary of the study's results and the conclusion are presented in Chapter V. It focuses on the impact of the study on the practice of product placement in both 
Hollywood and Bollywood and the contribution it has made to the existing literature. It also discusses the possibilities for future research on product placement. 


\section{CHAPTER II}

\section{REVIEW OF THE LITERATURE}

To analyze the practice of product placement, it is essential to discuss the meaning of the term product placement. It is also of crucial importance to understand how advertisers and film producers have used this practice to their advantage in both the Hollywood and Bollywood film industries. This literature review begins with the definition and meaning of product placement. It then provides a brief overview of the history of Hollywood and the practice of product placement in Hollywood movies followed by a brief history of Bollywood and product placement in Hindi movies.

\section{Definition and Meaning of Product Placement}

Scholarly definitions of product placement primarily focus on placing products in the broadcast media for money. Balasubramanian (1994) referred to it as a hybrid message - a paid message aimed at influencing movie (or television) audiences via the planned and unobtrusive entry of a branded product into a movie. Maynard and Scala (2006) described product placement as a strategic marketing tactic, the process through which an advertiser pays to place a product in a movie. They called product placement an alternative route for traditional overt advertising. Karrh (1998) defined brand placement as a paid inclusion of branded products or brand identifiers through audio and visual means within mass media programming, noting that the term product placement is used interchangeably with brand placement. Product placement refers to a product placed in a movie, when it is actually a brand that is placed in a movie. A company is usually interested in featuring its brand and not just any product. The Coca-Cola 
Company features Coca-Cola and not just any soft drink. For the purpose of this review, however, product placement and brand placement are indistinguishable.

\section{The American Film Industry: Hollywood}

“The term 'motion pictures' means the device as well as the art,” according to Balio (1976). In other words, the motion picture that is known as one of the biggest art forms did not originate as an art form at all but as a machine. The "motion picture" was essentially a mechanism that showed moving pictures.

The inventions in the decade of the 1890s were important for the American-movie industry. On April 14, 1894, the first customers for motion pictures paid to experience the new picture machine in the world's first kinetoscope parlor in New York City, and the saga of the American film industry began (Balio, 1976; Labosier, 2004). This machine showed moving pictures in a box. Just two years later, the motion picture projector was introduced, and several companies started producing simple films which were projected on a screen. In 1895, the famous Biograph was added to the line of existing projectors, and by the first decade of the twentieth century, entertainment demand grew to the point where film producers started exchanging their films. Until 1920, films were shown in restaurants or parks instead of special theatres. They were usually called nickelodeon because the admission ticket was typically five cents (Jennings, 1963; Segrave, 2004). The film entrepreneurs gradually built a cinema audience and started the mass production

of films. Apart from the production company that handled finances, there were just two more participants involved in this process of film making. These were a director who took care of plot, cast, location, and editing of the film, and a cameraman who handled 
lighting, shooting, and negative processing (Balio, 1976). The Great Train Robbery (1903) by Edwin S. Porter was the first movie to have a full-length picture story (Jennings, 1963; McClure, 1983).

Despite some initial resistance, the industry continued to develop, and, by 1908, thousands of people attended the movies regularly (McClure, 1983). As Jennings (1963) rightly suggested, motion pictures were such a new affair at the beginning of the twentieth century that many film producers, as well as the films produced during that era, were credited as being first-time achievements. However, D. W. Griffith is usually credited with originating the basic grammar of a film (Jacobs, 1968; Jennings, 1963; McClure, 1983).

During World War I, many European film industries collapsed as a result of the strain of war, and the American film industry became the world’s leading producer of motion pictures. During the same period, film producers started the "star system" and publicity campaigns for their films (McClure, 1983).

All the early cinema productions in the United States were made in New York, Chicago, and Philadelphia. Eventually, in the search for good weather and a way to avoid taxes, several producers started exploring the West Coast. The artificial lighting of the New York studios could not match the ideal weather conditions in California for outdoor shooting. Bronco Billy Anderson of the Essanay Company was the first to bring his production unit to California. He was followed by the Selig Company, which opened the first studio in California, and then many others followed (Jennings, 1963). Sam Goldwyn, Cecil B. De Mille, and Jesse Lasky, the three partners, searched Hollywood, a 
small village near Los Angeles, for an ideal site to set up a studio. They found what they were looking for and set up in a rented barn at the corner of Selma and Vine Streets (Jennings, 1963). Because of the instantaneous growth of the motion picture industry in Hollywood, people started referring to the industry by the name of the village itself, and Hollywood was born.

Prior to the 1920s few movie makers had experimented with background sounds or music in the movies, but none of those movies had any dialogue. Although The Jazz Singer (1927) by Warner Brothers is widely credited as being the first movie ever to have dialogue in it, The Lights of New York (1928), also by Warner Brothers, had dialogue throughout the entire movie (Jennings, 1963).

The Academy of Motion Picture Arts and Science and the Motion Picture Producers and Distributors of America are two of the most important motion picture institutions. Motion Picture Producers and Distributors of America was founded in 1922, and it later played an important role in the practice of product placement in films (McClure, 1983).

The motion picture industry has played a central role in the lives of Americans since its inception. The tremendous popularity of movies in the early days was matched only by the popularity of the church (McClure, 1983). During the Great Depression, they not only reflected political, social, and economic problems, but also became an outlet for the American audience's emotions. The movies became more mature with every passing year. The actors and actresses went through the same conflicts as the audience, and thus 
the audience could relate to them easily (McClure, 1983). The movie stars were in a great position to influence the audience.

Thus, what started with the simple machinery of moving pictures, has become a billion dollar industry today with the immense potential to influence the audience.

\section{Product Placement in Hollywood Cinema}

Although most authors date product placement back to the 1930s, Newell, Salmon, and Chang (2006) provided evidence that the first product placement actually took place in 1896 in the movie Washing Day in Switzerland. The movie producers entered into an agreement with Francois-Henri Lavanchy-Clarke, a Swiss businessman who functioned as an European distributor and promoter for the U.K. soap manufacturer, Lever Brothers, and produced Washing Day in Switzerland. One of the scenes in the movie includes two cases of Lever Brothers' soap prominently placed in front of two women washing clothes (Newell, Salmon, \& Chang, 2006).

Although Lumière brothers can be credited with producing a movie containing the first product placement, its true potential was recognized by Thomas Edison. Many Edison films such as A Ride Through the Pack Saddle Mountains (1899), A Romance of the Rail (1903), and Streetcar Chivalry (1905) included shots of transportation, such as railroads, for which the transportation companies paid money (Newell, Salmon, \& Chang, 2006).

Segrave (2004) noted that advertisement slides were the most popular form of movie advertising among marketers during the nickelodeon era. The advertising that existed towards the end of the silent movie era consisted of mainly one-reel ad shorts. 
No Hollywood majors such as Fox, Universal, or Paramount were involved in any of this type of advertising because they neither saw enough profit in this business to enter into it nor did they want to anger the audience and cinema operators whenever they came across such advertising. With the arrival of the sound era, advertising films started getting publicity, and then came the concept of the one-reel sponsored movie (Segrave, 2004). The sponsored movies did not include any direct advertising. They had a single credit line before or after the movie. Paramount and Warner Brothers set up different departments to cater to these sponsored shorts and the longer industrial films. By 1931 the majors started charging their advertisers; by May of 1931, more than 50\% of all U.S. cinemas had paid advertising (Segrave, 2004). It received a little push when the studios started sending scripts to marketers with promotional opportunities pointed out to them (Rothenberg, 1991). Although industrial films or short ads were more preferred by advertisers than product placements in movies, advertisers made the effort to place products such as costly cars, jewelry, expensive furnishings for the set, and costumes (Segrave, 2004).

Segrave (2004) argued that the slow development of the practice of product placement was because newspapers and Hollywood majors such as Fox were against the practice, believing that it would deprive them of the money they would earn in newspaper ads or educational films. In fact, the American audience was not thrilled to see products advertised in a movie. Segrave further stated that, to discourage the practice of product placement, the Motion Pictures Producers and Distributors of America formulated a 
policy against direct advertising in films and put a ban on brand-name references in several movies.

However, despite the ban and policies, product placement did take place on a limited scale. MGM’s 1931 release, Easiest Way, carried publicity for seven national advertisers (Segrave, 2004). Endorsement tie-ups and merchandising became more and more popular among advertisers and movie producers. When Gone with the Wind (1940) was released in Atlanta, the sales of retail tie-in merchandise skyrocketed and reached $\$ 636,250$. The manufacturers, each from a different area, were given licenses by MGM to sell the merchandise (Segrave, 2004). This trend of merchandising has continued and grown beyond imagination. A successful example of this trend is the movie, Lion King, for which Disney produced 186 items of merchandise for sale (Lubbers \& Adams, 2004).

The ban on advertisements appearing onscreen did not last more than six months. During the 1930s it was almost lifted, and product placement started becoming more of a common practice for Hollywood film makers (Segrave, 2004). In the 1940s a few Hollywood films such as Mildred Pierce (1945) and Angel on My Shoulder (1946) had product placements (Wenner, 2004). A few films from the 1950s also had some product placements but none was able to exploit their potential.

By the late 1960s it had become quite a routine affair for producers to contact advertisers regarding placing their products in films. Companies such as Columbia Pictures maintained a contact list for the tie-up merchandise that included the products, company names, and addresses (Newell, Salmon, \& Chang, 2006). Strangers When We Meet (1960) by Columbia Pictures involved a subplot where a key character in the story 
builds a house for a best-selling author. Instead of creating a movie set for the house, an actual house was built in Bel Air, CA, and scenes were filmed before, during, and after construction. Columbia publicist Marty Weiser raised \$100,000 worth of products from 14 manufacturers and trade associations and succeeded in reducing the construction cost to a large extent (Newell, Salmon, \& Chang, 2006). Movie directors started producing films with reality-based themes and included actual brands in those films. In Who's Minding the Store (1963) by Paramount Pictures, Jerry Lewis played a salesman working in a department store, which naturally gave numerous opportunities to feature consumer goods. In the end, the companies featuring their products in this film together supplied about \$1.5 million in products. The public relation chief of the Lewis Organization was motivated to request of some of the companies not to buy too many magazine ads promoting the movie and their products (Segrave, 2004).

By the 1970s and 1980s, product placement became more of a revenue source for the studios, which were struggling to keep up with the increasing costs of production and advertising (Brands, 1991; Galician \& Bourdeau, 2004). In fact, in the early 1980s product placement in the movies was prevalent (Segrave, 2004). The American audience's attitude towards product placement was changing, and it silently accepted the Budweiser beer featured in Honeysuckle Rose (1980) and Urban Cowboy (1980), the Cheerios in Honky Tonk Freeway (1981), and the Wheaties in Rocky III (1982) (Segrave, 2004). However, it was Reese's placement in E.T., the Extra-Terrestrial (1982) that brought the practice into the spotlight and caught the audience's attention (Gupta \& Lord, 1998). 
In truth, E.T. featured several products such as Coca-Cola, Pizza Hut, Raid, Fresca, Coors, and Reynolds, but it was Reese’s Pieces that created the greatest sensation. The original arrangement intended was for E.T., the alien in the movie, to follow a trail of M\&Ms to a destination, but the company withdrew. So instead of M\&Ms, Kathleen Kennedy, co-producer of E.T., negotiated with Hershey’s to use Reese’s Pieces. Hershey’s spent about \$1 million to promote both the candy and the movie. The placement was a huge success for Hershey's as the sales of the featured product soared. Industry sources noted that the sales temporarily tripled, but Hershey’s contended that sales increased by 65\% (Karrh, 1998; Newell, Salmon, \& Chang, 2006). Most communication scholars considered this to be a milestone in the history of product placement, primarily because it marked an era of acceptance in a positive attitude towards product placement. Since then, the practice of product placement in the movies has steadily increased. In the last two decades, some major movies have had such extravagant product placements that many among the laypersons are able to provide their details and history. Following are a few examples of such product placements.

Numerous advertisers see James Bond films as a perfect opportunity to showcase their products. Golden Eye (1995) featured the BMW Z3 Roadster, the placement for which the car company paid about $\$ 3$ million to the movie producers. The money spent by the company certainly paid off. The placement helped BMW earn $\$ 240$ million in advanced car sales (Hammer \& Brown, 1997; Maynard \& Scala, 2006). For the film, Tomorrow Never Dies (1997), MGM engaged five big advertisers: Heineken, Smirnoff, BMW, Visa, and Ericsson. These companies' worldwide spending was about \$98 
million, allowing MGM to double its marketing budget (Hammer \& Brown, 1997). These sponsors also were involved in the creative development of the film; its famous motorbike chase was added after director Roger Spottiswoode paid a visit to BMW's Munich factory.

According to Farhi (1998), America Online (AOL) almost “acted like a co-star” in Warner Brothers’ You've Got Mail (1998). There are several shots of the website, the instant messaging template, and the logo of AOL in the movie. The two voice messages, “you have got mail” and "goodbye,” with which many Americans were familiar, were repeated several times in the movie. The actors Tom Hanks and Meg Ryan mouthed the same words along with the message. AOL was almost a partner in the movie, and the executives worked with the film makers on several details including the title of the film. The title was changed from "You Have Mail” to "You've Got Mail” to match the exact AOL phrase (Farhi 1998).

Cast Away (2000) featured several brands such as Snickers, Dr. Pepper, FedEx, and Wilson; the latter two played significant roles in the movie (Maynard \& Scala, 2006). According to Maynard and Scala (2006), the total time of FedEx's product placement exposure in the movie was more than 15 minutes and Wilson's exposure was even more than that. However, the authors mentioned that the placement of Wilson was an “authentic inspiration” in the script and not merely a monetary condition. The authors argued that the onscreen exposure of Wilson in the movie is almost equivalent to Twentyone 30-second commercials, and the actual name is voiced 37 times. As for FedEx, although no money changed hands, FedEx supplied resources such as airplanes, trucks, 
packages, and uniforms to the movie producers. Also, it is no coincidence that FedEx CEO Fred Smith was an investor in the film’s production company (Friedman, 2004).

After the Hollywood blockbuster, The Matrix (1999), grossed more than $\$ 460$ million globally (Proffitt, Djung, \& McAllister, 2007), advertisers started looking forward to the sequel, The Matrix Reloaded (2003). The sequel prominently featured products such as the Cadillac CTS and the Samsung phone. There are many such examples of product placement that one can find in movies, including 2008 releases such as Sex and the City and Wall-E.

For the past three decades, product placement has become an important part of the marketing strategies of companies. Marketers find it useful, especially now, because of the flood of media advertisements, to use product placement to help break through advertising clutter (Olson, 2004). Sensing the potential market presented by product placements, several advertising companies such as Omnicom, MediaVest, Carat Americas, and many others have started special branded entertainment divisions to handle brand placements. The companies not only maintain close ties with Hollywood production houses, but also remain physically accessible to them to sustain the relationship. For example, Clarke Osborne, Nissan North America's product placement planner, remained in Southern California to be close to Hollywood even after Nissan moved its headquarters to Tennessee (Graser, 2007). Branded Entertainment Marketing Forecast: 2008-2012 (n.d.), a report by PQ Media on the product placement industry, provides data indicating that advertisers consider product placement as one of their best 
marketing strategies. According to the report, paid product placement spending grew by $34 \%$ to reach $\$ 2.9$ billion in 2007.

In recent years, advertisers have become increasingly concerned about where and how their products appear onscreen, paid or unpaid. They have been more vigilant, withholding the permission to use their products in scenes they think could set a negative tone. Slumdog Millionaire (2008) by Danny Boyle originally included some footage showing the brands Coca-Cola and Mercedes-Benz. Both companies denied permission to include their brands in particular scenes of the movie (Brodesser-Akner, 2008). Mercedes-Benz asked the producers to remove the logo from the car in a scene where it was shown roaming around in the slums. The company did not want to associate the Mercedes brand with slums. What they did allow, however, was the brand to be used in a scene where the car is shown parked outside an upscale house. Similarly, Coca-Cola asked the producers to remove the brand from a scene where a beggar offers a bottle of Coke to the protagonists of the movie (Brodesser-Akner, 2008).

With every film featuring several products in it and, with some companies making product placement their central marketing strategy, it may seem that the next step in product placement will be even more product placement. However, the recently released Wall-E (2008) has shown that there is more to it. This Disney Pixar movie is full of product placements, but what catches the attention of the audience is that Apple has achieved more than just placing a single product into a movie. With its shiny and allwhite robot female heroin, Eva, the movie emphasizes Apple’s entire design approach. In fact, Apple CEO Steve Jobs, who owned Pixar before selling it to Disney, is now on 
the board of directors, and Apple's chief designer Jonathan Ive played an important role as a consultant in designing Eva (Bulik, 2008). Wall-E provides evidence that product placement trends in the industry are changing, and that the practice is becoming more of a central strategy in the marketing campaign of a company.

\section{The History of Indian Cinema and Bollywood}

The announcement in July of 2003 by the Oxford English Dictionary that it accepted the word Bollywood and defined it as Indian cinema did not amuse everyone in the Indian Cinema Industry. The news received a mixed reaction. Some thought that, after many years, the Indian cinema finally got the recognition it deserved but others, including several actors, directors, and other professionals, criticized the decision. Actor Rahul Bose stated that "Bollywood” refers to just the mainstream Hindi film industry when there is actually much more to it. Indian cinema includes numerous regional film industries in addition to Hindi films. According to Subhash Ghai, a director, it wasn’t even the people from the Hindi film industry who acknowledged it as Bollywood. He noted that the first time the term "Bollywood” was used, it was in the BBC's coverage of the film, Ram Lakhan (1989). BBC said that the Bombay film industry was copying the style of Hollywood in terms of costumes and fashion, and so the Bombay film industry could be called Bollywood (Bollywood in Oxford Dictionary, 2003). So, unlike Hollywood, Bollywood did not get its name from an actual place. In this study, the entire Hindi film industry located in Mumbai is referred to Bollywood.

In 1910 Dhundiraj Govind Phalke (popularly known as Dadasaheb Phalke) was struck with the idea of making a feature-length film while watching a short documentary, 
The Life of Christ, at P. B. Mehta's America-India cinema in Mumbai (Agnihotri, 1990; Kaur \& Sinha, 2005; Mujawar, 1969). Until then, only foreign films from Hollywood and Europe were frequently distributed in the country (Thomas, 2005). Phalke decided to make his first film on "Indian gods," and thus the first feature film in Indian cinema was born. Raja Harishchandra (King Harishchandra) (1913), Phalke’s film, was the first in line among the many Hindu mythological films that followed. Before the film was released, R. G. Torney made a film on a Maharashtrian (a state in India) saint, Pundlik. However, since it was made by an Englishman, many scholars do not acknowledge it as the first Indian film (Kaur \& Sinha, 2005). Many critics later noted that, although early Indian films, including Raja Harishchandra, did not have equal impact on all the people in India (such as Muslims), they certainly started the era of motion pictures (Kaur \& Sinha, 2005). Until the 1920s, more than $90 \%$ of the films distributed in India were foreign films. It took a few more years for the number of Indian films to grow. Finally, sound technology arrived in the Indian cinema, and the first film with sound, Alam Ara (Beauty of the World), was released on March 14, 1931 (Thomas, 2005).

European and Hollywood cinema had a strong impact on the early Indian producers and directors. Phalke was not only inspired by foreign cinema but had visited Europe three times. Himanshu Rai, one of the early producers, trained with Georg Pabst and Erich Pommer at Germany’s most prestigious studio, UFA (Thomas, 2005). Among the early film makers, the Wadia brothers were the enthusiastic young owners of Wadia Brothers’ Productions. Theirs was a big business with almost 600 people on the payroll by the mid-1930s. Many Hollywood film directors, producers, technicians, and actors 
visited Mumbai, and Homi Wadia made sure that they visited the Wadia studio. He not only openly acknowledged the influence of Hollywood cinema on their films but also made many of their films based on several foreign films (Thomas, 2005).

Bombay Talkies was another big studio in the 1930s. Started by producer Himanshu Rai and his wife and actress Devika Rani in 1935, the studio released its first film Achhut Kanya (Untouchable Girl) in 1936 (Mishra, 2002; Thomas, 2005). V. Shantaram was another well-known director and one of the early producers in the history of Bombay cinema (Shantaram \& Narwekar, 2003). He started working in the Maharastra Film Company at a very young age and directed his first film, Netaji Palkar, in 1927. In 1929, he, along with four other partners, founded Prabhat Film Company in Kolhapur. Several of his movies were well received by the critics (Shantaram \& Narwekar, 2003).

Kaur and Sinha (2005) and Mishra (2002) stressed that all the early films in India mirrored the social and political situation around them. The early films were primarily based on the fight for independence and other social issues. Himanshu Rai’s Achhut Kanya (Untouchable Maiden) (1936) addressed the issue of the caste system in India. The Wadia brothers covered the Indian freedom fight in many of their films. For example, in Hunterwali (Woman with the Whip) (1935), the protagonist fought for her rights and to reclaim her kingdom from a treacherous tyrant. V. Shantaram also portrayed the Indian social environment in his movies such as Aadmi (Human) (1939). What started with a mythological cinema in the early 1920s turned toward the social genre in the 1930s, remained so until the 1960s, and then was dominated by Amitabh 
Bachchan’s “Angry Young Man” image of fighting against rich and corrupt politicians and gangsters. In the early 1990s the trend turned to romantic movies and has continued ever since (Kripalani, 2006).

Bollywood has always represented the cultural and social background of India and has always been inspired by the customs and life of Indian people. That, in turn has inspired people's dreams and fantasies. Overall, it has always been very close to the hearts of the Indian people.

\section{Product Placement in Bollywood Cinema}

The Indian film industry has always been a two-way street (Kripalani, 2006). It has reflected the customs and culture of Indian society and has set societal trends. The Indian audience has always been emotionally involved with onscreen actors. It has always looked to the actors and actresses for new trends, fashions, and hairstyles. Actors such as Dilip Kumar, Dev Anand, and actresses such as Sadhana, Asha Parekh, and Helen were famous for their costumes and hairstyles. Amitabh Bachchan has always been an onscreen voice for the poor, and Shah Rukh Khan has represented the younger generation. Thus, it did not come as a surprise when advertisers and marketers saw mainstream cinema as an opportunity to advertise their products and to rely on stars to set trends for costumes, accessories, and many other products.

Unfortunately, there is little research about product placement in the early Hindi movies. Some of the early movies featured a few brands; however, there are no accounts available to determine whether those placements took place in exchange for money. Coca-Cola was ahead of the game even in Bollywood movies. In a scene from the film 
Shree 420 (Mr. 420) (1955) when Raj Kapoor, the protagonist, enters Mumbai for the first time, a large Coca-Cola banner was visible right above his head. In Chalti Ka Naam Gaadi (The One That Moves Is a Vehicle) (1958), the story revolved around three brothers who own an auto repair shop. Several scenes in the film featured a poster depicting Mobil brake fluid along with at least one mention of it by one of the primary characters. In the movie, An Evening in Paris (1967), Coca-Cola was featured more than once. The hero and heroine of the movie carried a Coke bottle everywhere they go, and an entire crate of Coke was clearly visible in one of the scenes. Koshish (Efforts) (1972) also had a crate of Coca-Cola placed right beside the protagonist in a scene. Rajdoot motorcycle was featured in Raj Kapoor’s Bobby (1975), starring Rishi Kapoor and Dimple Kapadia. The motorcycle was associated with the movie in such a way that it was famously known as the Bobby motorcycle among consumers. These examples provide evidence that product placement is definitely not a new trend in the Hindi cinema industry.

The practice of placing brands in Bollywood films for money began in the late 1990s (Kripalani, 2006). Yash Chopra’s Dil To Pagal Hai (The Heart is Crazy) (1997) featured several brands such as Pepsi, Levis, and Killer jeans. The 1998 release Bandhan (Bond), starring Salman Khan and Rambha, included an entire scene in which the heroine insists on having a Pepsi with the hero. However, it was Taal (The Rhythm) (1999) by Subhash Ghai, which played the same role in Bollywood that E.T. played in Hollywood in 1982. It was after Coca-Cola's placement in Taal that people started becoming aware of the practice of product placement. Coke was featured very prominently in Taal. The 
main characters in this movie were shown not only drinking Coke but also saying the product name during their conversations. The brand was associated with emotional aspects of the movie such as friendship and love. The marketing group of Coca-Cola declared to have paid 200,000 rupees (\$4,260 USD) to close the deal, although according to an industry rumor, it was about one million rupees (\$21,300 USD) (Kripalani, 2006).

One of the most common trends in Indian movies is to have celebrities endorse products for which they are brand ambassadors. Aishwarya Rai, the brand ambassador for Coke, has starred in movies such as Taal (1999) and Kuchh na Kaho (Don’t Say Anything) (2003), which had Coke’s placement. Hero Honda motorcycles were featured in the movies Kabhi Khushi Kabhi Gham (Sometimes Happiness Sometimes Sadness) (2001), Aap Mujhe Achhe Lagane Lage (I Started Linking You) (2002), and Koi Mil Gaya (I Found Someone) (2003). All these movies starred Hrithik Roshan, who is the brand ambassador for Hero Honda. His image as a well-built youth riding the bike is appealing to Honda’s young target market. Kabhi Khushi Kabhi Gham (2001) included a huge variety of product placements such as several stores, shows, women’s magazines, and food chains such as Starbucks and Burger King. Koi Mil Gaya (2003) not only featured Bournvita, but it also included a scene where the protagonist talks about its advantages (Kripalani, 2006).

Like Hollywood, Bollywood film makers have also been exploring different types of product placement. Apart from just a brand placement in a movie or a prominent character talking about it, the producers have started placing a product integral to the storyline. The 2002 film Road, shot mostly on roads with the lead characters driving the 
cars, featured Tata Motors' Safari 4-wheel SUV. For this placement, Tata Motors paid about 12.5 million rupees (\$266,250 USD) (Kripalani, 2006). The trend of weaving a product into the storyline has become common in the Hindi film industry in the past few years. In fact, recent films such as Fashion (2008) and Dostana (Friendship) (2008) included several brands that were integral to the movies' themes. Fashion featured products such as Sunshine and Kimaya, which the protagonist, who is a model, endorses. The storyline of Dostana included one of the main characters working for the magazine Verve.

Several such films can be named for their product placements, especially the films released in the last five years. Most Bollywood movie producers now have separate departments to handle product placements in their movies. Since this type of advertising is likely to grow, it is important to study the practice in detail.

\section{Overview and Analytical Framework}

Research has shown that product placement in Bollywood and Hollywood movies is a standard practice. Studies by Newell, Salmon, and Chang (2006) and Segrave (2006) provide a historical perspective on the emergence of Hollywood and the practice of product placement in Hollywood. Research conducted by Kripalani (2006), Mishra (2002), and Thomas (2005) provided information on the emergence of Bollywood as well as the practice of product placement in Bollywood. McClure (1983) stated in his research that Hollywood movies have always reflected the political, social, and economic environment in America. Kripalani (2006) came to the same conclusion about Bollywood and the Indian movie audiences. He added that Bollywood movies have not 
only reflected the environment but also the customs and cultures of the audiences from different regions. Newell, Salmon, and Chang (2006) provided evidence that the practice of product placement in Hollywood is almost as old as the motion picture industry itself. After attracting audiences' attention in the 1980s, it has become a billion-dollar industry and has shown the potential for further growth. Although product placements came later to Bollywood, they have become a standard industry practice.

Galician and Bourdeau (2004) examined the practice of product placement in 15 Hollywood movies, five each from 1977, 1987, and 1997. They evaluated the number of product appearances, duration of product placements, types of products placed, primary association of brands with the characters, theatrical contexts of brands, and the integration of the brands into the storyline. Their research provided invaluable guidance for the selection and the measurement of variables used in this study. Another scholarly work important for the foundation of this study was the research conducted by Kripalani (2006) on trendsetting and product placement in Bollywood films. The definitions for most of the elements of product placement in this study were based on these two studies of Bollywood and Hollywood product placements.

Norm Marshall \& Associates Inc., an international firm specializing in placing brands in the entertainment media, has developed a method to determine the level of product placement. When applied to this study of product placement in films, it helped to determine which brands use what level of product placement and how frequently. The study analyzed the elements of product placements in the selected movies and compared the findings of the research for both Bollywood and Hollywood films. The research also 
helped to determine the trends in the practice of product placement during the period from 2005 to 2009. The overall research question was as follows: What are the similarities and differences in the practice of product placement between Bollywood and Hollywood movies from 2005 to 2009 ?

\section{Research Questions}

A study of the top three box-office hit movies from Bollywood and Hollywood for the years 2005 to 2009 was conducted to answer the following research questions:

1. How many product placements were used in Bollywood and Hollywood movies in each of the years from 2005 to 2009, and which brands appeared more frequently in both the industries?

2. What is the difference, if any, between product placements in Bollywood and Hollywood movies from 2005 to 2009 with respect to product categories and subcategories?

3. What is the difference, if any, between product placements in Bollywood and Hollywood movies from 2005 to 2009 with respect to the duration of product placements and the duration of brand name visibility?

4. What is the difference, if any, between product placements in Bollywood and Hollywood movies from 2005 to 2009 with respect to the presentation of product placements and the primary association of product placements?

5. What is the difference, if any, between product placements in Bollywood and Hollywood movies from 2005 to 2009 with respect to theatrical context and integration to the storyline?

6. What is the difference, if any, in the level of product placements in Bollywood and in Hollywood movies from 2005 to 2009? 


\section{CHAPTER III}

\section{METHOD}

The purpose of this study was to determine the similarities and differences between product placements in both the Bollywood and Hollywood film industries. The method used to answer the research questions was content analysis. The varied nature of placements in movies, along with numerous elements of product placement, makes it difficult for scholars to formulate a single framework to assess all the brand placements and put them into predetermined categories. Thus, to evaluate product placement in a movie, it becomes necessary to evaluate its elements and to organize the elements into different categories. To determine these elements of product placement, the research conducted by Galician and Bourdeau (2004) on the evolution of product placement in Hollywood cinema was primarily utilized. The research was conducted by analyzing the audio and video elements of 30 movies included in the sample. To create a common platform for comparison, 15 elements of product placement were defined, which were then analyzed to answer the research questions.

\section{Sample}

The sample consisted of 15 movies from Hollywood and 15 movies from Bollywood. The unit of analysis was the entire movie. The study period was 2005-2009. The sample selection criterion was the box office revenue of the movies. The top three box-office hits for each of the five years from both Bollywood and Hollywood were selected. The secondary criterion for sample selection was the genre of the movies. The sample included movies from drama, action, comedy, adventure, romance, crime, and 
horror genres. However, animation movies, science-fiction movies, fantasy movies, period movies, and children's movies were excluded since these types of movies are very new and still emerging genres in Bollywood.

The website http://www.boxofficeindia.com was used to access and shortlist the top three Bollywood box office hits from 2005 to 2009. Following is the list of movies included in the study: 
Table 1

List of Bollywood movies included in the sample

\begin{tabular}{|c|c|c|}
\hline Year & Movie Title & Genre \\
\hline \multirow[t]{3}{*}{2005} & No Entry & Comedy \\
\hline & Bunty Aur Babli & Comedy/Adventure \\
\hline & Maine Pyaar Kyun Kiya & Comedy \\
\hline \multirow[t]{3}{*}{2006} & Dhoom: 2 & Action \\
\hline & Krissh & Adventure \\
\hline & Lage Raho Munnabhai & Comedy/Drama \\
\hline \multirow[t]{3}{*}{2007} & Om Shanti Om & Action/Drama \\
\hline & Welcome & Comedy/Crime \\
\hline & Chak De India & Drama \\
\hline \multirow[t]{3}{*}{2008} & Ghajini & Action/Drama \\
\hline & Rab Ne Bana Di Jodi & Comedy/Drama \\
\hline & Singh is King & Action/Comedy \\
\hline \multirow[t]{3}{*}{2009} & 3 Idiots & Comedy \\
\hline & Love Aaj Kal & Comedy \\
\hline & Chandni Chowk to China & Action/Comedy \\
\hline
\end{tabular}

To access and shortlist the top three Hollywood movies for last five years, the websites http://www.the-numbers.com/market/ and http://www.boxofficemojo.com were used. Following is the list of movies selected for study: 
Table 2

List of Hollywood movies included in the sample

\begin{tabular}{|c|c|c|}
\hline Year & Movie Title & Genre \\
\hline \multirow[t]{3}{*}{2005} & The War of the Worlds & Action/Adventure \\
\hline & Wedding Crashers & Comedy \\
\hline & Charlie and the Chocolate Factory & Comedy \\
\hline \multirow[t]{3}{*}{2006} & X-Men: The Last Stand & Action \\
\hline & The Da Vinci Code & Mystery/Thriller \\
\hline & Casino Royale & Action Adventure \\
\hline \multirow[t]{3}{*}{2007} & Spider-Man 3 & Adventure \\
\hline & The Bourne Ultimatum & Action/Adventure \\
\hline & National Treasure: Book of Secrets & Action/Adventure \\
\hline \multirow[t]{3}{*}{2008} & The Dark Knight & Action/Crime \\
\hline & Iron Man & Action \\
\hline & Hancock & Action \\
\hline \multirow[t]{4}{*}{2009} & The Hangover & Comedy \\
\hline & The Blind Side & Biography/Drama \\
\hline & Night at the Museum: Battle of the & Action/Adventure \\
\hline & Smithsonian & \\
\hline
\end{tabular}




\section{Measures}

For each selected film, 15 product placement variables were studied, and the findings were compared to determine the current trends and the annual as well as overall similarities and differences between product placements in Bollywood and Hollywood movies. These variables were based on the most frequently analyzed elements of product placement listed among the scholarly studies referenced in the literature review. Each film’s rank at the box office and each film's genre were also noted in the coding.

Following is a list of variables, measures, and their definitions. For more details on variable descriptions and coding categories, see Appendix A.

1. Product category: Each product appearing onscreen was assigned to one of the 24 predetermined product categories, such as apparel and electronics.

2. Product subcategory: This category provided more detailed information about the product category. Each of the 24 categories was further divided into subcategories. For example, electronics was subdivided into 14 subcategories, such as TV, camera, and mobile. Each brand appearing onscreen was assigned to one of the product subcategories.

3. Duration of product appearance: The time duration for which each product appeared on the screen was measured with the help of a stopwatch. To achieve a recognizable placement of a product, that is, for a viewer to realize that he or she is looking at a familiar brand, the product must be onscreen for a minimum of 1.5 to 3 seconds. Thus, the duration of the product placement proves to be very important, especially when the product is only visible and not used or mentioned. 
4. Duration of brand name visibility: The time duration for each brand name appearance onscreen was measured with the help of a stopwatch. Advertisers placing their brands in the movies are careful about how their product appears onscreen. They want to ensure that, along with the brand, other important features of the product are also visible. For example, if an advertiser pays to place its brand onscreen for 45 seconds, it is not necessary that its logo be onscreen for the entire time. This is why the total duration of product appearance and the duration of brand name visibility were coded as separate variables.

5. Type of product placement: Types of product placement in a movie were different than types of products. Each product placement in each movie was divided into the following three categories:

1. Seen: When the product was visible on the screen.

2. Mentioned: When the product was mentioned by name by any of the characters in the movie.

3. Used: When the product was used by any of the characters in the movie.

6. Primary association of a brand with a character: Product placements were differentiated on the basis of their primary association with a star or no-star as follows:

1. With a Star: When a brand appearing onscreen was used by, or mentioned by, or was in any way associated with a star in the movie, which may consist of a hero/heroes, or a heroine/ heroines, or a villain/villains. 
2. With a Non-Star: When a brand appearing onscreen was used by, or mentioned by, or was in any way associated with any of the characters in a movie except a hero/heroes, or a heroine/ heroines, or a villain/villains.

3. With none of the characters: When a brand appearing onscreen was just seen or heard and was in no way associated with any of the stars or non-star characters in the movie.

7. Theatrical context of brand placement: The context in which a product was used in a scene of a movie was measured by this variable. Each brand placement was assigned to one of three categories:

1. Positive: When a brand was used or mentioned in some positive context or emotions by any of the characters in any scene in a movie, for example, a group of friends drinking a soft drink and enjoying themselves or a character playing a video game for fun.

2. Negative: When a brand was used or mentioned in a negative context or emotion by any of the characters in any of the scenes in a movie, for example, a gangster using a motorcycle.

3. Neutral: When a brand was just visible or heard in the background of a scene with no reference to it or use of it by any of the characters in a movie, for example, a banner with a company name visible in the background of a scene where two of the characters are just talking to each other. 
8. Integration into the storyline: This dichotomous measure was used to determine whether a brand was integral to the storyline or whether it was just used as one of many brands in a movie.

9. Level of product placement: Based on the method developed by Norm Marshall \& Associates to analyze the level of product placement in the movies, three levels of product placement were identified - Levels A, B, and C. Each brand placement was assigned one level. The levels of product placement were as follows:

1. Level A: This level of product placement of a brand delivered all of the six characteristics.

2. Level B: This level of product placement of a brand delivered four or five of the six characteristics. It included an action in the scene using the product or a featured exposure of the brand identity.

3. Level C: This level of product placement of a brand delivered up to three of the six characteristics. The exposure may be delivered via background signage, recognizable logo, or product identity near the scene’s primary action.

The following is a list and definitions of the six characteristics which determined the levels of product placement:

1. Appropriateness: It measured how the placement of a product fits the product itself and the intended use. If a character in a movie is drinking a soft drink in a particular scene, then it can be concluded that 
the product delivers against the characteristic of appropriateness. However, if a soft drink bottle is just visible in a particular scene of a movie and is not being used as a soft drink, which is its intended use, then it can be said that the product does not deliver against this characteristic.

2. Impression - When the placement provided a readable image of the product and if a viewer could identify the product and its name, it was considered to have delivered an impression.

3. Implied Endorsement - If a character in a movie was in any way endorsing or promoting the product appearing onscreen, then the product was coded as delivering an implied endorsement.

4. Verbal Reference - If the placement had a positive and/or neutral reference to the product, then it was a verbal reference to the product.

5. Brand Message - When the placement delivered a positive image about the product or brand, it was considered to be delivering a brand message.

6. Integration - When the product appearing onscreen was integral to the storyline, it was regarded as integration.

\section{Pre-test}

A pre-test was conducted to determine whether the variables identified by the researcher were consistent with the current trends in the product placement industry and whether it was necessary to change the established measures to gain more relevant 
information from the content analysis. Two movies, one from Bollywood and one from Hollywood, were analyzed. After analyzing the results for the pre-tests, the variable duration of product placement was split into two different variables, one measuring the entire duration and one measuring just the duration of brand name visibility. Two additional product categories, cigarettes and finance, were added to the list of existing product categories.

\section{Reliability}

The researcher was the primary coder. To determine intercoder reliability through Scott's pi, a second coder was trained. The second coder coded two randomly selected movies from Bollywood and two randomly selected movies from Hollywood. To train the second coder on question three, certain keywords and phrases such as shot angles were utilized.

All variables measured had a very high level of intercoder reliability. The overall reliability was .97 across all the 15 elements analyzed. Eleven of the fifteen variables had a perfect Scott's pi of 1. The variables - duration of product placement and brand name visibility - had a Scott's pi of .87 and .91, respectively. The other two elements were impression, .94 and brand message, .91. 


\section{CHAPTER IV}

\section{RESULTS}

\section{Overview of the Results}

Overall, transportation was the most frequent category to appear in Bollywood and Hollywood movies. The next prominent categories were electronics and publishing. In the product subcategories, the most dominant subcategory was cars. In terms of brands, Mercedes led the way when combined the brands in both movie industries. Almost $80 \%$ of the brands appearing onscreen were used by characters in the movies; very few brands were only seen, and even fewer were only mentioned. Not surprisingly, the percentage of positive product placements in the movies was higher than negative product placements. It was also noticed that level B product placement was more popular among the advertisers than level A or level C.

Mercedes was the brand that was most frequently found in Bollywood. However, in Hollywood, Ford made more appearances than Mercedes. Among electronics, Sony, the second most frequent category, was found in both Bollywood and Hollywood. Apparel and entertainment subcategories were found more in Bollywood than in Hollywood. In terms of duration of brand appearances, Bollywood and Hollywood product placements were significantly different in the years 2006 and 2007. Brand integrations into the storylines were significantly higher in Hollywood than Bollywood. Finally, of the six characteristics defining the level of a product placement, a significant difference was found with respect to the appropriateness, implied endorsement, and verbal reference. As compared with Hollywood, significantly fewer product placements 
were appropriate, were endorsed by the characters in the movies, and were verbally referred to in the Bollywood movies.

The similarities and differences between product placement practices in Bollywood and Hollywood are discussed in detail in the following sections.

\section{Research Questions}

Research Question 1: How many product placements were used in Bollywood and Hollywood movies from 2005 to 2009, and which brands appeared more frequently in each of the industries?

The analysis of 30 movies showed that there were a total of 299 product placements, an average of 10 for each movie. Of the 299 placements, 129 were found in Bollywood movies and 170 were found in Hollywood movies. Almost 200 different brands were identified in the selected 30 movies, out of which a few were common in both the industries. The number of brand appearances in Hollywood movies varied from 10 to 50 per year, as compared with Bollywood's 25 to 30 per year.

The largest number of product placements was found in 2007. The Hollywood movie, The Bourne Ultimatum (2007), featured 25 brands, most of which were cars. The total number of brands appearing in the top three Hollywood movies produced in 2007 was 50. In contrast, only a few brands were found in the top three Hollywood movies in 2005. There were no brands found in Charlie and the Chocolate Factory, and the other two movies from 2005 featured only 10 brands combined. In Bollywood, two movies in every year except 2006 featured Mercedes Benz. However, in Hollywood, only four movies featured Mercedes: two in 2007, one in 2006, and one in 2009. There were three 
occasions when more than one product from the same brand appeared in one movie. In the movie, Dhoom: 2 (Blast) (2006) from Bollywood, four different Sony products were featured. In Hollywood, three different LG products appeared in the movie Iron Man (2008), and two different products from Apple appeared in the movie National Treasure: Book of Secrets (2007).

The results showed that one single brand did not dominate product placements in both the industries. However, brands such as Mercedes, Sony, Ford, BMW, Nokia, and Samsung appeared more frequently than others. Six car appearances from Ford were noted in Hollywood movies followed by four appearances of Mercedes. In Bollywood, Mercedes was the most frequent brand to appear onscreen followed by Sony and Samsung. Brands such as Nokia, BMW, Nike, Apple, and LG appeared in both Bollywood and Hollywood. A few brands appeared in just one of the two industries. Reliance, Jet Airways, and Air India appeared only in Bollywood, and Ford, Cadillac, and VTech appeared just in Hollywood. Interestingly, about 75\% of the brands appeared only once or twice whereas a few, such as Mercedes and Sony, appeared more frequently. Results showed that Mercedes appeared onscreen more frequently than others. It appeared in 8 of the 15 movies from Bollywood and 4 of the 15 movies from Hollywood. It was one of the few brands that delivered all the six defined elements of level of product placement and thus had a level A placement. Most of the Mercedes appearances were associated with the stars of the movies in both the industries. Particularly in Bollywood, it was frequently used as a status symbol. 
In the case of cars, Ford was the most popular brand used in Hollywood movies. Ford made more appearances in Hollywood movies than Mercedes. The reason behind these Ford appearances in Hollywood movies is that police cars were usually Ford models. BMW and Cadillac were the other two car brands that appeared more than once in Bollywood and Hollywood movies.

Sony scored as the second most frequent brand among the 30 movies. It appeared in nine movies, five from Bollywood and four from Hollywood. It was the most noticed brand among electronics. Several Sony products such as monitors, video cameras, phones, laptops, and TVs were used as props in the movies.

Overall, almost 140 brands appeared just once in the 30 movies. Most of these brands were associated with either a primary or a secondary character.

Today, advertisers are so actively involved in the marketing of a movie that the buzz of a brand placed in a movie corresponds with the buzz of the movie itself. The recent brand placement of Van Heusen in the 2008 Bollywood blockbuster, Ghajini, is a good example of this phenomenon. News stories about Van Heusen, a major men’s apparel brand, creating an entire line of clothing for actor Aamir Khan in Ghajini appeared in newspapers and in social media such as blogs and websites even before the movie’s official promos were aired. Aamir Khan’s Ghajini wardrobe, along with his character's special haircut, was publicized very systematically. Aamir Khan did not just talk about the brand in several of his interviews but he also participated in a fashion show and walked down the runway for the promotion of Van Heusen along with Ghajini. The videos of this program are available on websites such as www.youtube.com. 


\section{Research Question 2: What is the difference, if any, between product placements in Bollywood and Hollywood movies from 2005 to 2009 with respect to product categories and subcategories?}

Product Categories. A list of 24 product categories that were identified for classification is displayed in Appendix A. Table 3 shows that advertisers from transportation companies, electronics companies, and media entities such as publishing and entertainment were aggressive in the practice of product placement. In both Bollywood and Hollywood, as Table 3 shows, advertisers from the transportation industry (32.8\%) were more aggressive than other industries. The electronic industry followed with $22.4 \%$. The third most frequent category to appear in the movies combined from the two industries was media. In Hollywood, publishing was the third most frequent category but in Bollywood it was entertainment. As Table 3 shows, other frequent categories in the two industries were apparel, food and beverage, and destinations. The audience's increased dependency on the vast knowledge available on the Internet provides an opportunity for software advertisers to incorporate the use of these websites and software programs in movies, especially when the movies depict dayto-day life. Overall, about $80 \%$ of the products came from the first five categories shown in Table 3, and the other 20\% came from the remaining 14 categories. 
Table 3

Frequencies of major product categories in Bollywood and Hollywood movies

\begin{tabular}{lccc}
\hline Product categories & Bollywood & Hollywood & Combined \\
& Percent & Percent & Percent \\
& $(\mathrm{n}=129)$ & $(\mathrm{n}=170)$ & $(\mathrm{n}=299)$ \\
\hline Transportation & 38.0 & 28.8 & 32.8 \\
\hline Electronics & 21.7 & 22.9 & 22.4 \\
\hline Media & 12.5 & 13.5 & 13.1 \\
\hline Publishing & 4.7 & 9.4 & 7.4 \\
\hline Entertainment & 7.8 & 4.1 & 5.7 \\
\hline Apparel & 8.6 & 3.0 & 6.0 \\
\hline Clothing & 4.7 & 0.6 & 5.7 \\
\hline Food/Beverage & 5.4 & 5.9 & \\
\hline
\end{tabular}

Note. The media category included the combined percentages of publishing, entertainment, and music videos, and the apparel category included combined percentages of apparel, footwear, and fashion. Table 3 displays only the prominent categories.

Because fashionable clothing is an inevitable part of Bollywood movies, apparel companies found numerous opportunities to advertise their brands. Results showed that six apparel brands appeared in the Bollywood movies studied. Of those, five were international brands and only one was Indian. As noted earlier, one of the brands was 
Van Heusen, which captured audience attention in a very distinct sales campaign. Van Heusen created an entire line of clothing for the protagonist in a movie and promoted it in a very strategic manner. As a result, the audience was looking forward to seeing the movie for the Van Heusen clothes as much as for the movie itself. However, with the exception of a selected few such as Van Heusen, very few fashion designers or apparel companies are currently exploiting the true potential that Bollywood presents. Equally surprising, a single sports-apparel brand was noticed in just one of the Hollywood movies.

In case of entertainment category, there were more product placements in Bollywood than in Hollywood movies. Bollywood movies had 7.8\% of the total brands from the entertainment category as compared with Hollywood's 4.1\%. Interestingly, results showed that almost all the brands from the entertainment category were integrated into the storyline of the movies.

The product categories appearing onscreen did not vary much from year to year with the exception of 2007. In the other four years, the most frequent category to appear onscreen in both Bollywood and Hollywood was transportation. In 2005, the second most frequent category in Hollywood movies was stores, malls, and restaurants but, in Bollywood movies, it was electronics. In the years 2006 and 2009, transportation was the top category, followed by electronics. However, in 2007 more products from the electronics category were featured in the movies than transportation. Most of the product placements from the publishing industry in Hollywood movies occurred in 2008. 
Statistical Analysis. Independent sample t-tests were conducted to determine whether there were differences between the two industries with respect to each of the four major product categories. There were no significant differences between Bollywood and Hollywood movies; $t$-test results are as follows: transportation, $t(297)=1.674, p=.095$; electronics, $t(297)=-.253, p=.800$; media, $t(297)=-.285, p=.775$; and apparel $t(297)=$ $1.589, p=.113$

Product Subcategories. A total of 67 product subcategories were found in the 30 movies. As shown in Table 4, the most frequent subcategory was cars in both industries. In Bollywood and Hollywood movies combined, a total of 68 automobile appearances were noticed. Cars accounted for $22.7 \%$ of all products placed in the 30 movies. More than 25 brands of cars were shown in 25 of the 30 movies with five brands common to both industries. Presenting a car in a car chase was quite frequent and appeared to be the most preferred product placement by advertisers. 
Table 4

Frequencies of product subcategories in Bollywood and Hollywood movies

\begin{tabular}{|c|c|c|c|c|c|}
\hline \multirow[t]{2}{*}{$\begin{array}{l}\text { Product } \\
\text { subcategories }\end{array}$} & Bollywood & \multirow[t]{2}{*}{$\begin{array}{c}\text { Product } \\
\text { subcategories }\end{array}$} & Hollywood & \multirow[t]{2}{*}{$\begin{array}{c}\text { Product } \\
\text { subcategories }\end{array}$} & \multirow{2}{*}{$\begin{array}{c}\text { Combined } \\
\text { Percent } \\
(\mathrm{n}=299)\end{array}$} \\
\hline & $\begin{array}{l}\text { Percent } \\
(\mathrm{n}=129)\end{array}$ & & $\begin{array}{l}\text { Percent } \\
(\mathrm{n}=170)\end{array}$ & & \\
\hline Cars & 22.5 & Cars & 22.9 & Cars & 22.7 \\
\hline $\begin{array}{l}\text { Mobile } \\
\text { phones }\end{array}$ & 10.1 & $\begin{array}{l}\text { Laptops and } \\
\text { computers }\end{array}$ & 8.2 & $\begin{array}{l}\text { Mobile } \\
\text { phones }\end{array}$ & 8.0 \\
\hline Airlines & 8.5 & Mobile phones & 6.5 & $\begin{array}{l}\text { Laptops and } \\
\text { computers }\end{array}$ & 7.0 \\
\hline $\begin{array}{l}\text { Laptops and } \\
\text { computers }\end{array}$ & 5.5 & $\begin{array}{l}\text { Restaurants/ } \\
\text { eateries }\end{array}$ & 6.5 & Airlines & 4.7 \\
\hline TV channels & 5.4 & Magazines & 5.9 & TV channels & 4.7 \\
\hline \multirow[t]{2}{*}{ Motorbikes } & 5.4 & Websites & 4.1 & $\begin{array}{l}\text { Restaurants / } \\
\text { Eateries }\end{array}$ & 4.3 \\
\hline & & TV channels & 4.1 & & \\
\hline Other & 42.6 & Other & 48.3 & Other & 44.6 \\
\hline
\end{tabular}

Of the 30 movies analyzed, 9 Hollywood and 6 Bollywood movies included car chases. The car companies were ahead of the game in product placement, and, on several occasions, product placements were central to their marketing strategies. For example, Maruti, a well known car company in India, placed its new model, Swift, in the movie Bunty Aur Babli (Bunty and Babli), (2005). Company officials had a clever strategy for introducing this car. The producers and the Maruti company worked together to have the 
car used by the protagonists in the movie. The producers and the company representatives did not reveal the role Swift played in the movie ahead of its release, and then both the car and the movie were released simultaneously on May 27, 2005, generating a lot of excitement about the new car featured in the movie. As a result, the company sold more than 30,000 vehicles in its first quarter (Kripalani, 2006).

The second most frequent subcategory in both Bollywood and Hollywood was mobile phones. There were 24 mobile phone appearances in Bollywood movies with nine different brands. More than $80 \%$ of the time, mobile phones were used by the primary characters in the movie. Of the remaining 20\%, Vodafone was only visible in one of the movies and Reliance and Blackberry were the only two brand names that were voiced by the characters.

In Hollywood, laptop and computer appearances were more frequent than mobile phones. Eight different brands of laptops and computers made 14 appearances. Bollywood featured laptops and computers 7 times in 5 out of 15 movies.

In Bollywood, the third most advertised product subcategory was airlines with 8.5\%, but in Hollywood it was mobile phones with 6.5\%. Other subcategories to appear frequently in Bollywood were laptops and computers (5.5\%), TV channels (5.4\%), and motorbikes (5.4\%); in Hollywood, they were restaurant and eateries (6.5\%), magazines (5.9\%), websites (4.1\%), and TV channels (4.1\%). Of the 12 brands of magazines that appeared in the 30 movies combined, 10 were noted in Hollywood, and only 2 were noted in Bollywood movies. Of the 10 brands in Hollywood movies, 7 appeared in only one movie, Iron Man (2008). The movie starts with profile information of the 
protagonist where, with the help of several magazine articles, the character Tony Stark has been established to be a very intelligent industrialist. TV channels appeared seven times in Bollywood and six times in Hollywood.

The increased dependency on technology in people’s day-to-day lives was reflected in the movies as well. Several brands placed in the movies came from either the automobile industry or the electronics industry.

\section{Research Question 3: What is the difference, if any, between product placements in Bollywood and Hollywood from 2005 to 2009 with respect to the duration of product placements and the duration of brand name visibility?}

A company placing its product in a movie tries to make the placement as effective as possible. To achieve that, the company and the producers have to find a balance between the audience noticing the product, and the product becoming a distraction in a movie. In addition to displaying the logo and name of a product, several companies attempt to showcase the prominent features of their products. For example, car manufacturers like to showcase new designs or additional features such as the interior of their cars. Thus, advertisers may use the time devoted to their product placements to not only display their logos but also to display their products. It was noticed that many cars placed in the movies were shot from different angles to display their logos, looks, comfort, and speed.

To understand how much time the advertisers prefer to allocate to the display of the logo and to the display of the entire product, the duration of the placement was divided into two variables. The first variable was a measure of the duration of time for 
which the product was onscreen, and the second was the duration of the onscreen visibility of the brand.

Of 299 brand appearances, 101 were featured in such a way that the name or logo was visible for the entire time the product was onscreen. Of these 101 brands, most were placed for three to eight seconds. However, there were a few instances when the brand name visibility lasted for more than 50 seconds. For example, Coca-Cola was placed in the Bollywood movie, Dhoom: 2 (2006), for 118 seconds with its logo visible the entire time. Similarly, the Indian News channel, Aaj Tak, was placed in the movie Chak De India (2007) for 77 seconds. Only two other brands were placed for more than 60 seconds in the movies and had their logos visible the entire time. Seventeen brand appearances out of the 101 lasted just for one second.

The movie Ghajini (2008) portrayed the protagonist as a once successful businessman who abandons everything in his life to revenge his girlfriend's death. The story has a lot of flashbacks where the protagonist is shown as a businessman in classy shirts and suits, which were designed by Van Heusen and introduced as the Ghajini collection. The duration of time the actor wears the Van Heusen clothes was counted. Results showed that the actor wore the Van Heusen clothes for almost 28 minutes, which accounted for about $15 \%$ of the runtime of the movie. The length of the Van Heusen placement was unusual. The next highest time for which a brand was placed in a movie, was Mercedes, which was placed for 6.5 minutes. As many as 18 brands were just mentioned but not shown in the movies, with 11 in Hollywood movies and 7 in Bollywood movies. In addition, there were 21 brands that were shown in the movies but 
their onscreen time was not long enough to be calculated. These products were recognized by the coder based on their design features.

In Ghajini (2008), there were 16 product placements, which accounted for a little more than 33 minutes - almost 18\% of the runtime. Although, as noted above, Van Heusen alone was onscreen for 28 minutes, the actual brand name was visible for only one second. As Table 5 shows, because of the length of the Van Heusen placement, the total duration of combined product placement of 2008 Bollywood movies was more than double the duration of Hollywood movies.

In 2009, however, the overall duration of product placements in Hollywood movies was more than the duration of product placements in Bollywood movies. The Blind Side (2009) featured three major brands, Under Armour, Schutt, and BMW, for a little under 600, 350, and 250 seconds, respectively. These product placements resulted in the total of Hollywood product placements in 2009 reaching to more than 2,300 seconds. 
Table 5

Duration of combined product placements per year

\begin{tabular}{lcc}
\hline Year & $\begin{array}{c}\text { Bollywood } \\
\text { (Seconds) }\end{array}$ & Hollywood \\
& (Seconds) \\
\hline 2005 & 920 & 336 \\
2006 & 1257 & 661 \\
2007 & 2243 & 690 \\
2008 & 980 & 827 \\
\hline
\end{tabular}

Although there were more brands in Hollywood movies than in Bollywood movies, the duration of total product placements was longer in Bollywood movies. Table 5 shows that in 2005 the duration of the combined product placements in Bollywood movies was more than in Hollywood movies. This dramatic difference was primarily because Charlie and the Chocolate Factory, one of the top three Hollywood movies of 2005, did not have a single product placement. Also, the other two movies featured very few products. As a result, in 2005, the duration of product placements in Bollywood movies was more than double the duration of product placements in Hollywood movies. The difference was less pronounced in the year 2006, but increased in the following two years. The placement of the McDonald and Ultratech Cement brands contributed to the increase in the duration of product placement in 2007. In 2008, Van Heusen alone accounted for more than $75 \%$ of the combined duration of product 
placements. The year 2009 stands out in Table 5 because it was the only year when product placements in Hollywood movies were of longer duration than in Bollywood movies. Of the brands featured in Hollywood movies from 2009, at least four were shown for longer than 100 seconds throughout the movies, The Hangover and The Blind Side, and several others were shown for more than 50 seconds.

Overall, the placement duration in Bollywood films was mostly consistent during the five years, but it steadily increased with each passing year in Hollywood movies.

Statistical Analysis. Independent sample t-tests were conducted to determine whether there were differences between Bollywood and Hollywood with respect to the overall duration of product placements each year. Results showed that there were no significant differences between the two industries in the years 2005, 2006, 2008, and 2009. The results for overall duration of product placements are as follows: $2005, t(36)=$ $-.040, p=.968 ; 2006, t(51)=.707, p=.483 ; 2008, t(70)=1.286, p=.203$; and 2009, $t(59)=-.368, p=.714$. However, in 2007, the difference between product placements in the two industries was significant. Table 6 shows the t-test result for year 2007.

Table 6 Independent sample t-test for overall duration of product placements

\begin{tabular}{cccccc}
\hline Year & \multicolumn{2}{c}{ Means } & Df & $t$ & $p$ \\
& Bollywood & Hollywood & & & \\
& & & & & \\
\hline 2007 & 45.00 & 13.80 & 73 & 4.192 & $<.0001$ \\
\hline
\end{tabular}


The visibility of a brand name was measured by the amount of time the actual logo or the brand name was visible onscreen. Table 7 demonstrates the combined duration of brand name appearances in the movies from each of the five years.

\section{Table 7}

Duration of combined brand name appearances per year

\begin{tabular}{lcc}
\hline Year & $\begin{array}{c}\text { Bollywood } \\
\text { Seconds }\end{array}$ & Hollywood \\
& 455 & 76 \\
2005 & 594 & 219 \\
2006 & 650 & 375 \\
2008 & 271 & 475 \\
2009 & 237 & 1080 \\
\hline
\end{tabular}

There were 21 brand appearances where the brand name or logo was not visible, and 18 instances where neither the product was seen onscreen nor the brand name was visible. Similar to the duration of overall product placement, the duration of brand name visibility was longer in Bollywood movies than in Hollywood movies for the first three years. In 2008, however, although the overall duration of product placement was longer in the Bollywood industry, the combined brand name visibility was greater in Hollywood. Van Heusen, featured in the Bollywood movie Ghajini (2008), was again the key factor responsible for this turnaround. Van Heusen suits designed for the character were worn for almost 1700 seconds in the movie. However, the actual brand name was visible for 
only one second. This unique case of product placement was reflected in the calculation for duration of placements in 2008 - increasing the overall placement duration substantially while keeping the combined duration of brand name visibility small. Finally, the movie with the longest time of brand name appearances was The Blind Side (2009) from Hollywood, which greatly contributed to the overall increase in the duration of brand name visibility for that year. These appearances were of the sports brands Under Armour and Schutt along with BMW.

Statistical Analysis. Independent sample t-tests were conducted to determine whether there were differences between Bollywood and Hollywood with respect to the duration of brand name appearances by year. There were no significant differences between the two industries in the years 2005, 2008, and 2009. The results for duration of brand name appearances are as follows: $2005, t(36)=1.371, p=.179 ; 2008, t(70)=$ $.274, p=.785$; and 2009, $t(59)=-.957, p=.343$. In 2006 and 2007, the differences between the two industries were significant. Table 8 shows the t-test results for 2006 and 2007.

Table 8

Independent sample t-test for duration of brand name appearances

\begin{tabular}{cccccc}
\hline Year & \multicolumn{2}{c}{ Means } & $d f$ & $t$ & $p$ \\
& Bollywood & Hollywood & & & \\
& & & & & \\
\hline 2006 & 22.00 & 8.42 & 51 & 2.349 & $<.023$ \\
\hline 2007 & 20.72 & 7.50 & 73 & 3.376 & $<.001$ \\
\hline
\end{tabular}


Research Question 4: What is the difference, if any, between product

placements in Bollywood and Hollywood movies from 2005 to 2009 with respect to the presentation of product placements and the primary association of product placements?

Presentation of Product Placement. When measuring the evolution of product placement in Hollywood, Galician and Bourdeau (2004) measured the types of product placement. Based on the same variable, this study measured the presentation of product placement. This variable directly relates to the financial aspect of product placement. The advertisers pay more money when the product is not only seen but is also used or mentioned by a character in the movie. Table 9 shows the frequencies of product placement by category.

Table 9

Frequencies of presentation of product placement for Bollywood and Hollywood brand appearances

\begin{tabular}{lccc}
\hline Presentation of Product Placement & $\begin{array}{c}\text { Bollywood } \\
\mathrm{n}=129\end{array}$ & $\begin{array}{c}\text { Hollywood } \\
\mathrm{n}=170\end{array}$ & $\begin{array}{c}\text { Combined } \\
\mathrm{N}=274\end{array}$ \\
\hline Percent & Percent & Percent \\
Used & 79.8 & 85.9 & 83.3 \\
Seen & 14.7 & 8.2 & 11.0 \\
Mentioned & 5.4 & 5.9 & 5.7 \\
\end{tabular}

Note. The number of brands that were both used and mentioned in a movie was very small and so they were included in the "used" category. 
Results showed that having a character from the movie use the brand was the preferred practice of advertisers, who feel that the actual use of the brands is more effective than just showing them on the screen. Seeing the movie star drive a specific car or drink a particular soft drink creates an affinity in the viewers' minds toward the product. Of the 299 brands, 83.3\% were used onscreen by either a primary or a secondary character in the movie. Eleven percent of the brands were just seen and not used in the movies, and $5.7 \%$ of the brands were just mentioned. However, only a small number of brands were both used and mentioned by a character in the movie. Of the 249 "used” product placements in the movies, only 9 brand names were mentioned. The time for which these brands were used onscreen varied by movie. Some brands were used in just one scene, but brands such as Van Heusen, as noted in the previous example, were used through the entire movie.

The difference between the frequencies indicated in Table 9 is very striking. Based on these frequencies, it is apparent that placing the products in the hands of the actors in the movies and showing them use the products onscreen was preferred by advertisers. Of the 299 brand appearances, 240 brands were used by the characters in the movies, which accounted for about $80 \%$. For statistical purposes, the categories "used" and "used and mentioned” were combined into one category. The second preferred method of placement was "seen,” followed by “mentioned."

Statistical Analysis. An independent sample t-test showed that there was not a significant difference between the two industries with respect to the presentation of product placement $(t(297)=-1.655, p=.099)$. 
Primary Association of the Product Placement. This variable was also based on the research conducted by Galician and Bourdeau (2004). It was divided into three categories based on who used the product in the movie. Although, the choice of preference of the advertisers in both Bollywood and Hollywood movies was the same, the percentages slightly varied. More than $60 \%$ of the product appearances were associated with the lead characters in the movies. The advertisers believed that having the product associated with a star gives more credibility to the brand and makes the viewers desire it. A little more than $25 \%$ of the product appearances were associated with a secondary character, and very few products were shown with no character association.

Statistical Analysis. Independent $t$-test was calculated to determine the difference between Bollywood and Hollywood with reference to the primary association of product placement. The results of the test showed that the difference was not significant at the specified .05 level, $t(297)=-.367, p=.714$.

Research Question 5: What is the difference, if any, between product placements in Bollywood and Hollywood movies from 2005 to 2009 with respect to the theatrical context and integration to the storyline?

Theatrical Context of Product Placement. Advertisers are concerned about how the audience perceives a brand featured in movies. As a result, they are concerned about how the brand is portrayed (Brodesser-Akner, 2008). The results of this content analysis emphasized the fact that advertisers prefer to place their product in a positive context. Of 299 brands, 185 (61.9\%) were placed in a positive context. The previously stated example of the recent refusal by Coca-Cola and Mercedes to place their products in 
movies having a negative context indicates that advertisers are making conscious efforts to ensure that the brands are placed in a positive context. The secondary choice for placement was the neutral context (24.1\%). Very few advertisers allow producers to place their products in any negative context (14\%).

Statistical Analysis. An independent sample t-test showed that the difference between the two industries with respect to the theatrical context was not statistically significant $(t(297)=-.111, p=.912)$.

Integration of Product Placement. The analysis of this element revealed a prominent difference between product placements in Bollywood and Hollywood. In Bollywood, there was very little difference between the percentage of products integrated with the storyline (48\%) and products not integrated with the storyline (52\%). However, in Hollywood, not only was the percentage of brands integrated in the storyline (72.9\%) more than the percentage of brands not integrated (27.1\%), the difference between the two was much greater than that of Bollywood.

Statistical Analysis. The data coded for this variable confirmed that there is a difference between the two industries. Table 10 displays the cross tabulation of the integration of product placement in the storyline across the film industries. The results of a chi-square test showed that the difference between the brand integration in the storyline across the film industries was significant at $p<.0001$, indicating that Hollywood advertisers are more likely than Bollywood advertisers to have their brands integrated into the movies. 
Table 10

Chi-square for integration of product placement into the storyline across film industries

\begin{tabular}{lcc}
\hline Industries & Integrated & Not integrated \\
& $(n=186)$ & $(n=113)$ \\
\hline Bollywood & 62 & 67 \\
Hollywood & 124 & 46 \\
\hline
\end{tabular}

Note. $X^{2}(1, N=299)=17.823, p<.0001$.

\section{Research Question 6: What is the difference, if any, in the level of product placements in Bollywood and in Hollywood movies from 2005 to 2009?}

The level of product placement was based on six elements. The method for calculating the level of product placement was developed by Norm Marshall \& Associates. Before calculating the levels, the difference between each element was calculated.

Appropriateness. Based on how a product was used, its appropriateness was calculated. If the intended use of a product matched with the use of that product in a movie, then the placement was said to be appropriate; if it did not match, then it was labeled as inappropriate.

Statistical Analysis. The results of a chi-square test to determine whether there was a difference in the appropriateness of product placement across the industries is displayed in Table 11. The difference between Bollywood and Hollywood was significant with a $p<.0001$. 
Table 11

Chi-square for appropriateness of placement across film industries

\begin{tabular}{lcc}
\hline Industries & $\begin{array}{c}\text { Appropriate } \\
(n=237)\end{array}$ & $\begin{array}{c}\text { Not appropriate } \\
(n=62)\end{array}$ \\
\hline Bollywood & 101 & 28 \\
\hline Hollywood & 136 & 34 \\
\hline Note. $X^{2}(1, N=299)=102.425, p<.0001$. &
\end{tabular}

Impression. Based on whether the placement delivers a readable image of a product, the impression level of its placement was calculated. Of the 299 brands that were recorded, only 16 brand placements did not deliver the brand impression. In Bollywood movies, 122 brand placements delivered brand impressions and 7 did not deliver a readable image. In Hollywood movies, 161 brand placements delivered and 9 placements did not deliver the brand impressions. As the numbers of the brands that did not deliver this variable were very low, no statistical test could be performed. However, the raw numbers provide evidence that advertisers from both Bollywood and Hollywood prefer to have their brands deliver the brand impression.

Implied Endorsement. Based on whether a primary character in a movie uses or mentions a product, implied endorsement was calculated.

Statistical Analysis. Table 12 exhibits the results of a chi-square test that showed that the difference between the two industries in terms of implied endorsement was statistically significant at $p<.0001$. 
Table 12

Chi-square for implied endorsement across film industries

\begin{tabular}{lcc}
\hline Industries & $\begin{array}{c}\text { Implied endorsement } \\
(n=198)\end{array}$ & $\begin{array}{c}\text { No Implied endorsement } \\
(n=101)\end{array}$ \\
\hline Bollywood & 92 & 37 \\
\hline Hollywood & 106 & 64 \\
\hline Note: $X^{2}(1, N=299)=31.468, p<.0001$. &
\end{tabular}

Verbal Reference. When a product is mentioned in a movie, either by a character or in the background, it had what advertisers refer to as a verbal reference.

Statistical Analysis. A chi-square test was performed to find the significance of difference between the two industries in terms of verbal reference. Table 13 displays the results of the test that showed that the difference between the two industries in terms of verbal reference was statistically significant at $p<.0001$.

Table 13

Chi-square for verbal reference across film industries

\begin{tabular}{lcc}
\hline Industries & $\begin{array}{c}\text { Verbally referred } \\
(n=55)\end{array}$ & $\begin{array}{c}\text { Verbally not referred } \\
(n=244)\end{array}$ \\
\hline Bollywood & 25 & 104 \\
\hline Hollywood & 30 & 140 \\
\hline
\end{tabular}

Note. $X^{2}(1, N=299)=119.468, p<.0001$. 
Brand Message. A placement delivering a positive image of a brand also delivers a brand message. Not surprisingly, almost all brand placements in both Bollywood and Hollywood delivered a clear and strong brand message. Of the 170 brands featured in Hollywood, 168 brand placements had a brand message, and just two placements did not deliver a positive impression of brand. In Bollywood, 121 brand placements delivered brand messages, and 8 placements failed to do so. Here again, the number of brand placements not delivering the brand message was so low that no statistical test could be performed.

Integration. Findings on integration were discussed under Research Question 5. The chi-square test results for this variable are displayed in Table 10. The difference between the two industries was significant at $p<.0001$.

Level of Product Placement. For each placement, the six characteristics appropriateness, impression, implied endorsement, verbal reference, brand message, and integration - were used to determine the level of product placement. The method developed by Norm Marshall \& Associates was used to calculate the level of product placement. Level C product placement delivered up to three characteristics out of a possible six. Level B product placement delivered four to five of the six characteristics. Level A product placement delivered all six characteristics. Results showed that the level B product placement was the most often used by advertisers. There were very few brands that had level A product placement.

The price that the advertisers pay to place their brands in the movie is directly related to the level of product placement. As the level increases, so does the price. This 
may be the reason why the B level is most popular (see Table 14). Level C placement may seem inadequate, and level A may be too expensive for some advertisers. Level B, however, provides a balance between a good exposure to the product and the price advertisers have to pay for the placement.

Table 14

Frequency distribution of the level of product placement $(N=299)$

\begin{tabular}{lccc}
\hline Level of product & Bollywood & Hollywood & Combined \\
placement & Percent & Percent & Percent \\
& $(n=129)$ & $(n=170)$ & $(n=299)$ \\
\hline Level A & 8.5 & 4.7 & 6.4 \\
Level B & 67.4 & 77.6 & 73.2 \\
Level C & 24.0 & 17.6 & 20.4 \\
\hline
\end{tabular}




\section{CHAPTER V}

\section{CONCLUSION}

Product placement in movies has a 100-year history. In both Bollywood and Hollywood, it has become a common practice to feature brands in movies. Long ago, scholars realized the importance of studying product placement as an important marketing strategy. Newell, Salmon, and Chang (2006) wrote about the history of product placement across the Hollywood film industry. They talked about the origin of the term product placement, the forms it had taken since its birth, the early adopters of product placement, the practice of placement in TV and radio, and the marriage of art and commerce in films in general. Karrh (1998) briefly discussed the recent decades of development within the product-placement industry with regard to its financial and legal aspects and the audience's attitude toward brand placement. Galician and Bourdeau (2004) conducted a content analysis of 15 movies from the years 1977, 1987, and 1997 to analyze some key elements of product placement. Kripalani (2006) presented an overview of product placement in Bollywood, including the history of brand placement in the Indian cinema as well as the relationship between brand placements in Bollywood and the actors who served as brand ambassadors.

This thesis examined the top three box office hits in each year from 2005 through 2009 from Bollywood and Hollywood and analyzed each one for brand placements and compared those from one industry to the other. A content analysis was conducted on these 30 movies, which were selected based on revenue grossed at the box office. The author analyzed the brands that were used in the past five years, the type of product 
categories and subcategories that were aggressive, and the average duration of those brand placements. The author also examined how the brands were presented, who presented them, and whether they were integrated into the storyline. Finally, the author analyzed the level of product placement for each brand in each movie.

\section{Discussion}

Overall, brand placements in Bollywood movies were very similar to the placements in Hollywood movies. However, there were some differences between the two industries.

Although this study did not focus on the comparison between the genres of movies from Bollywood and Hollywood, movies from drama genre appeared more frequently in Bollywood than any other genre. More than $60 \%$ of Hollywood's top three box-office hits were action and adventure films, and none of the 15 movies was from the drama genre. The differences in movie genres in Bollywood and Hollywood may help to explain the reasons for particular types of products or categories or the particular presentation patterns being used more in one industry than in another.

The statistical tests showed that there was a significant difference between Bollywood and Hollywood with respect to the integration of brand with the storyline. More brands from Hollywood were integrated into the movies than the brands from Bollywood. There were also significant differences between the two industries in terms of appropriateness, verbal reference, and implied endorsement. The two industries were also significantly different with respect to the duration of brand name appearance in 2006 and 2007. 
This study examined what product categories appeared more frequently in Bollywood and Hollywood. In both the industries, product advertisers from the transportation, electronics, and publishing categories were the most aggressive. Among the subcategories, cars, mobile phones, airlines, magazines, computers, bikes, websites, and TV channels were the most prominently presented. The product placements in movies reflect people's everyday lives. Cars, mobile phones, and computers, which are integral to daily living for most people, dominated product placement in the film industries. The increasing dependence on websites for information and entertainment has given a boost to website advertising in movies. Several movie characters were shown using websites such as Google.com to access information. These placements were appropriate and well integrated into the storyline of the movies.

The content analysis conducted by Galician and Bourdeau (2004) showed that automobiles were the leaders in Hollywood product placements in 1977, 1987, and 1997. This analysis not only supports this earlier finding, but it also extends it by demonstrating that automobiles are leaders in the Bollywood product placement industry. However, with the exception of this dominant product category, placement categories in Hollywood have changed. For the three decades ending in 1997, the second dominant product category was food and beverages with beer and soda being the largest subcategories (Galician \& Bourdeau, 2004). Since then, however, Hollywood has changed, and the results of this study reflect recent technological developments. The second most dominant category after automobiles is no longer food and beverages. It is now electronics. The reason more transportation and electronic products are placed in movies 
is that the nature of movies has become more realistic, more modern, and more techsavvy. A couple of decades earlier, there was one James Bond movie per year, and people would look forward to seeing new cars, gadgets, and watches as much as the new Bond girls. Today, most movies feature cutting-edge technology, and more movies have car chases. Transportation and electronics now rule the field of product placement, reflecting the fact that mobile phones, laptops, and cars have become necessities of life. Interestingly, other media were also featured frequently in movies. For example, several magazine and newspaper brands were featured repeatedly in Hollywood movies, and TV channels were placed frequently in Bollywood movies. Most of the magazine or TV channel brands that appeared onscreen were associated with the stars of the movies. The "destinations" category included stores, malls, and restaurants. There were 14 appearances of such destinations in Hollywood movies. Several food-chain marketers, restaurant owners, and store owners are aware of the advertising product placements in movies present.

The Bollywood film industry, with its distinctive nature, provides a huge market for brands from fashion and apparel. Although some advertisers have become aware of the potential Bollywood movies present for fashionable clothing, not many are exploring it. Although six brands from the apparel industry were prominently placed in Bollywood films, this number is very low as compared with the total number of product placements in Bollywood movies. With the exception of the movie, Fashion (2009), which was not analyzed since it did not fit the selection criteria, manufacturers from the apparel and 
fashion industries in India seem to be taking less advantage of the brand placement opportunities in Bollywood movies.

In terms of branding, Hollywood made more product placements than Bollywood. Hollywood movies featured 170 placements as compared with Bollywood’s 129. The practice of product placement has changed since the late 1990s. Galician and Bourdeau (2004) found that Coke was the dominant brand in 1997. In the movies released between 2005 and 2009, no single brand dominated Hollywood or Bollywood. Of the total of 299 brands, 133 appeared just once in the movies. However, the brands that appeared more frequently than others were Mercedes and Sony. The wide range of brands appearing onscreen provides evidence that the product placement industry is not ruled by just one brand and that an increasing number of advertisers are adopting the product placement strategy in their marketing mix.

The duration of product placements in each movie was calculated with the help of a stopwatch. The overall duration of placements has increased with each passing year. The duration of brand name visibility in Bollywood movies varied in the range of $1.5 \%$ to $6 \%$ of the runtime of the movie. However, the duration of brand-name visibility in Hollywood movies has consistently increased over the years starting from as low as $0 \%$ of the runtime of the movie in 2005 to around $8.8 \%$ of the runtime of the movie in 2009 . The years 2006 and 2007 showed a significant difference in the duration of brand name appearance between the industries. In 2008, one of the apparel brands featured an entire range of clothing in a Bollywood movie, and, as a result, it ranked first in terms of the 
duration of brand placements in Bollywood. As for Hollywood, the year 2009 dominated both in the duration of brand placements and in the duration of brand name visibility.

The study showed that in most product placements the actors in the movies actually use the advertisers’ products. To achieve even more involvement for a brand in a movie, advertisers have to pay substantial sums of money. It can be concluded that advertisers try to achieve the most results in the least expensive way possible.

More than $60 \%$ of the brands appearing onscreen were associated with the primary characters in the movies. Advertisers' second preference was associating their products with secondary characters. Only slightly more than $13 \%$ were associated with none of the movie characters. This indicates that advertisers feel that the association of brands with the stars and their movie characters will help them reach the audience in a way that enhances the relationship of the audience to their products.

Not surprisingly, the majority of brands found in the movies were used in a positive context, although there were certainly some brands that were portrayed in either a neutral or negative context. However, it would be incorrect to conclude that these advertisers prefer to have their brands featured in a negative way. More appropriately, there is no evidence that the advertisers whose products or brands were featured in a negative context were insistent on having their product portrayed in a specific way. That being said, it must also be added that advertisers are becoming increasingly concerned about the way their brands are portrayed in films.

Hollywood movies had a greater number of brands integrated into the storyline, however, in case of Bollywood movies, the number of brands not integrated into the 
script was higher. It appears that the advertisers in Hollywood are more conscious than Bollywood advertisers about blending their brands into the movies as much as possible.

Finally, level B product placement was more frequent than levels A and C. As mentioned earlier, levels of product placement were defined based on six characteristics. Level A delivered all the six characteristics, level B delivered four or five of the six, and level C delivered up to three of the six characteristics. Since the money paid by advertisers is directly related to the level of product placement, they prefer the Level B product placement because it gives them more exposure than Level $\mathrm{C}$ and is more cost effective than Level A.

\section{Contributions to the Literature}

This study examined some of the most recent Bollywood and Hollywood films. The primary contribution of this study was regarding product placements in the Bollywood film industry. Although some research has been conducted on past and present practices of product placement in Hollywood, very little research has been done on product placement in Bollywood. As product placement has become more prominent in the Indian cinema, it is essential to get an overview of the current trends and practices of brands advertised in Hindi films.

This study was an extension of a content analysis conducted by Galician and Bourdeau (2004). A review of the literature found no studies that analyzed movies released between 2005 and 2009. Mass communication scholars and advertisers will benefit from this updated analysis of product placement. 
The third major contribution of this study is that this is the first study to compare product-placement practices in Bollywood and Hollywood movies. With Bollywood stars acting in Hollywood films and vice versa, advertisers are starting to realize the extended range of customer types that the films will be able to provide.

Finally, this study provides academics with insight into product marketing in the world's two largest movie producing industries. In addition, with the world turning into a single global market, advertisers are looking for the opportunity to market their products to customers from different backgrounds, different cultures, and different nations. This study will help those advertisers who seek to market their products internationally.

\section{Directions for Future Research}

This study examined the elements of product placement. The content analysis displayed fascinating results. However, it must be noted that the two film industries have different types of audiences with distinct cultures. It is possible that the audience's reactions to the brands placed in movies may be different from one industry to the other.

This study does not analyze the audiences’ reactions toward the advertisements in movies. It could be beneficial to conduct an analysis of audiences' responses to the product placements. Also, this study considers the brands placed only in the movies. Further research can be conducted to analyze the placements in other media such as TV, video games, the music industry, and even the Internet. It is possible that there may be differences between India and the United States in terms of brand placements in other media. 


\section{REFERENCES}

Agnihotri, Ram A. (1990). Social and Political Study of Modern Indian Cinema (past, present and future perspectives). New Delhi, India: Commonwealth Publishers.

Balasubramanian, Siva K. (1994). Beyond Advertising and Publicity: Hybrid messages and public policy issues. Journal of Advertising, 23(4), 29-46.

Balio, Tino (1976). The American film industry. Madison, WI: University of Wisconsin Press.

Bollywood in Oxford Dictionary. (2003, July 2). The Times of India. Retrieved from http://timesofindia.indiatimes.com/articleshow/54816.cms

PQ Media LLC. (n.d.). Branded Entertainment Marketing Forecast 2008-2012. Retrieved from http://www.pqmedia.com/branded-entertainment-marketing-2008.html

Brands on the screen; Rocky the salesman. (1991, April 20). The Economist, p. 70 (U.K. Edition p. 88).

Brodesser-Akner, Claude (2008). Coke, Benz avoid gritty ‘slumdog’ roles. Advertising Age, 79(42), 14-14.

Brown, Corie \& Hammer, Joshua (1997, December 15). Licensed to shill. Newsweek, p. 43.

Bulik, Beth S. (2008, July 21). Wall-E offers preview of branding 2.0; Disney Pixar’s running apple 'homage' may be model of what's to come. Advertising Age, 79(26), 6-6.

Dwyer, Rachel \& Patel, Divia (2002). Cinema India - The visual culture of Hindi film. London, England: Reaktion Books.

Farhi, Paul (1998, December 17). AOL gets its message out in 'Mail.' The Washington Post. Retrieved from http://www.washingtonpost.com/wpsrv/style/movies/features/aolinmail.htm

Friedman, Ted (2004). Cast away and the contradictions of product placement. Journal of Promotion Management, 10(1), 171-183.

Galician, Mary-Lou \& Bourdeau, Peter G. (2004). The evolution of product placements in Hollywood cinema: Embedding high-involvement 'heroic' brand images. Journal of Promotion Management, 10(1), 15-36.

Graser, Marc (2007, June 4). Clarke Osborne. Advertising Age, 78(23), S-14-S-14. 
Gupta, Pola B. \& Lord, Kenneth R. (1998). Product placement in movies: The effect of prominence and mode on audience recall. Journal of Current Issues \& Research in Advertising, 20(1), 47.

Jacobs, Lewis (1968). The Rise of the American Film: A Critical History with an EssayExperimental Cinema in America. New York, NY: Teachers College, Columbia University.

Jennings, Gary (1963). The Movie Book. New York, NY: The Dial Press.

Karrh, James A. (1998). Brand placement: A review. Journal of Current Issues \& Research in Advertising, 20(2), 31.

Kaur, Raminder \& Sinha, Ajay (2005). Bollyworld: An introduction to popular Indian cinema through a transnational lens. In Kaur, Raminder \& Sinha, Ajay. (Eds.). Bollyworld: Popular Indian Cinema through a Transnational Lens. New Delhi, India: Sage Publications India Pvt. Ltd.

Kripalani, Coonoor (2006). Trendsetting and product placement in Bollywood film: Consumerism through consumption. New Cinemas: Journal of Contemporary Film, 4(3), 197-215.

Labosier, James (2004). From the kinetoscope to the nickelodeon: Motion picture presentation and production in Portland, Oregon, from 1894 to 1906. Film History, 16(3), 286-323.

Lubbers, Charles A. \& Adams, William J. (2004). Merchandising in the major motion picture industry: Creating brand synergy and revenue streams. Journal of Promotion Management, 10(1), 55-63.

Maynard, Michael L. \& Scala, Megan (2006). Unpaid advertising: A case of Wilson the Volleyball in 'Cast Away.' Journal of Popular Culture, 39(4), 622-638.

McClure, Arthur F. (1983). Research Guide to Film History. Saratoga, CA: R \& E Publishers.

Mishra, Vijay (2002). Bollywood Cinema: Temples of Desire. New York, NY: Routledge.

Mujawar, Isak (1969). Maharashtra: Birthplace of Indian film industry. New Delhi, India: Chief Information Officer, Maharashtra Information Centre.

Newell, Jay., Salmon, Charles T., \& Chang, Susan (2006). The hidden history of product placement. Journal of Broadcasting \& Electronic Media, 50(4), 575-594. 
Norm Marshall \& Associates, Inc. (Producer). (n.d.). Entertainment \& Marketing. [VCD, Obtained from Norm Marshall \& Associates].

Olson, Scott. R. (2004). The extensions of synergy: Product placement through theming and environmental simulacra. Journal of Promotion Management, 10(1/2), 65-87. doi: 10.1300/J057v10n01_06

Proffitt, Jennifer M., Djung, Yune T., \& McAllister, Matthew P. (2007). Plugging back into the matrix. Journal of Communication Inquiry, 31(3), 239-254.

Rothenberg, Randall (1991, May 31). The media business; critics seek F.T.C. action on products as movie stars. The New York Times, p. 1.

Sauer, Abram (n.d.). 2008 Brandcameo Product Placement Awards. Retrieved from http://www.brandchannel.com/features_effect.asp?pf_id=435

Segrave, Kerry (2004). Product placement in Hollywood films: A history. Jefferson, NC: McFarland \& Company, Inc.

Shantaram, Kiran \& Narwekar, Sanjit (2003). V. Shantaram, the legacy of the Royal Lotus. New Delhi, India: Rupa \& Co.

Thomas, Rosie (2005). Not quite (pearl) white: Fearless Nadia, queen of the stunts. In Kaur, Raminder \& Sinha, Ajay. (Eds.). Bollyworld: Popular Indian Cinema through a Transnational Lens. (pp. 35-69). Sage Publications India Pvt. Ltd., New Delhi, India.

Wenner, Lawrence A. (2004). On the ethics of product placement in media entertainment. Journal of Promotion Management, 10(1), 101-132. 


\section{APPENDIX A}

\section{CODING GUIDE}

1. Year - The year in which each movie was released will be recorded as follows:

\begin{tabular}{|c|c|}
\hline Category & Code \\
\hline 2005 & 1 \\
\hline 2006 & 2 \\
\hline 2007 & 3 \\
\hline 2008 & 5 \\
\hline 2009 & \\
\hline
\end{tabular}

2. Film industry -

\begin{tabular}{|c|c|}
\hline Category & Code \\
\hline Bollywood Film Industry & 1 \\
\hline Hollywood Film Industry & 2 \\
\hline
\end{tabular}

3. Film ranking - Ranking of the film for each year will be recorded

\begin{tabular}{|c|c|}
\hline Category & Code \\
\hline Number one Box office Hit movie & 1 \\
\hline Number two Box office Hit movie & 2 \\
\hline Number three Box office Hit movie & 3 \\
\hline
\end{tabular}

4. Film name - Name of the film to be analyzed will be recorded 
5. Film genre - In case of a film with a combination of two genres, the prominent one will be considered.

\begin{tabular}{|c|c|}
\hline Category & Code \\
\hline Action / Adventure & 1 \\
\hline Action Thriller & 2 \\
\hline Adventure & 3 \\
\hline Family Adventure & 4 \\
\hline Period Adventure & 5 \\
\hline Comedy & 7 \\
\hline Drama & 8 \\
\hline Biography & 9 \\
\hline History & 10 \\
\hline Romance & \\
\hline
\end{tabular}

6. Brand name of product - Brand name of each product appearing on screen will be recorded.

7. Product category and subcategory - Each product appearing on screen will be allocated in the appropriate product category and subcategory.

\begin{tabular}{|c|c|c|c|}
\hline Product Category & Code & Product Subcategory & Code \\
\hline Fashion Accessories & 1 & Backpacks & 101 \\
\hline
\end{tabular}




\begin{tabular}{|c|c|c|c|}
\hline & & Belts & 102 \\
\hline & & Handbags & 103 \\
\hline & & Hats & 104 \\
\hline & & Caps & 105 \\
\hline & & Hosiery & 106 \\
\hline & & Jewelry & 107 \\
\hline & & Neckties & 108 \\
\hline & & Scarves & 109 \\
\hline & & Sunglasses & 110 \\
\hline & & Suspenders & 111 \\
\hline & & Watches & 112 \\
\hline & & Wallets & 113 \\
\hline & & Umbrellas & 114 \\
\hline Clothing & 2 & Beach wear & 201 \\
\hline & & Dresses & 202 \\
\hline & & Jackets & 203 \\
\hline & & Jeans & 204 \\
\hline & & Sportswear & 205 \\
\hline & & Suits & 206 \\
\hline & & Sweaters & 207 \\
\hline & & T-shirts / Shirts & 208 \\
\hline
\end{tabular}




\begin{tabular}{|c|c|c|c|}
\hline & & Designer wear & 209 \\
\hline \multirow[t]{8}{*}{ Household } & 3 & Bedding & 301 \\
\hline & & $\begin{array}{l}\text { Blankets / } \\
\text { Comforters }\end{array}$ & 302 \\
\hline & & Fabrics & 303 \\
\hline & & Appliances & 304 \\
\hline & & Clocks & 305 \\
\hline & & Glassware & 306 \\
\hline & & Picture frames & 307 \\
\hline & & Silverware & 308 \\
\hline \multirow[t]{8}{*}{ Electronics } & 4 & Cassette players & 401 \\
\hline & & Electronic games & 402 \\
\hline & & Personal stereos & 403 \\
\hline & & Telephones & 404 \\
\hline & & Television & 405 \\
\hline & & Mobile Phones & 406 \\
\hline & & Computers & 407 \\
\hline & & Laptops & 408 \\
\hline \multirow{3}{*}{$\begin{array}{l}\text { Food/ } \\
\text { Beverages }\end{array}$} & 5 & Candy & 501 \\
\hline & & & \\
\hline & & Cereal & 502 \\
\hline
\end{tabular}




\begin{tabular}{|c|c|c|c|}
\hline & & Cookies & 503 \\
\hline & & Frozen meals & 504 \\
\hline & & Ice cream & 505 \\
\hline & & Juice & 506 \\
\hline & & Snacks & 507 \\
\hline & & Soft drinks & 508 \\
\hline & & Chocolate & 509 \\
\hline Liquor & 6 & Beer & 601 \\
\hline & & Vodka & 602 \\
\hline & & Rum & 603 \\
\hline Footwear & 7 & Sandals & 701 \\
\hline & & Shoes & 702 \\
\hline & & Slippers & 703 \\
\hline & & Sneakers & 704 \\
\hline Furniture / Furnishings & 8 & Beanbag chairs & 801 \\
\hline & & Beds & 802 \\
\hline & & Bookcases & 803 \\
\hline & & Ceiling fans & 804 \\
\hline & & Chairs & 805 \\
\hline & & Tables & 806 \\
\hline & & Lamps & 807 \\
\hline
\end{tabular}




\begin{tabular}{|c|c|c|c|}
\hline \multirow[t]{10}{*}{ Health / Beauty } & 9 & $\begin{array}{l}\text { Adhesive } \\
\text { bandages }\end{array}$ & 901 \\
\hline & & Bathing accessories & 902 \\
\hline & & Combs and brushes & 903 \\
\hline & & Cosmetics & 904 \\
\hline & & Fragrances & 905 \\
\hline & & Shampoos & 906 \\
\hline & & Soaps & 907 \\
\hline & & Tissues & 908 \\
\hline & & Vitamins & 909 \\
\hline & & Medicines & 910 \\
\hline \multirow{6}{*}{$\begin{array}{l}\text { Infant / Children’s } \\
\text { Products }\end{array}$} & 10 & Baby bottles & 1001 \\
\hline & & & \\
\hline & & Bassinets & 1002 \\
\hline & & Infant clothing & 1003 \\
\hline & & Infant bedding & 1004 \\
\hline & & Infant toys & 1005 \\
\hline \multirow[t]{4}{*}{ Music / Video } & 11 & Books-on-tape & 1101 \\
\hline & & Cassettes & 1102 \\
\hline & & CDs & 1103 \\
\hline & & Prerecorded & 1104 \\
\hline
\end{tabular}




\begin{tabular}{|c|c|c|c|}
\hline & & videos & \\
\hline & & DVDs & 1105 \\
\hline \multirow[t]{7}{*}{ Publishing } & 12 & Books & 1201 \\
\hline & & Activity books & 1202 \\
\hline & & Calendars & 1203 \\
\hline & & Comic books & 1204 \\
\hline & & Magazines & 1205 \\
\hline & & Newspapers & 1206 \\
\hline & & Posters & 1207 \\
\hline \multirow[t]{11}{*}{ Sporting Goods } & 13 & Balls & 1301 \\
\hline & & Bicycles & 1302 \\
\hline & & Ice skates & 1303 \\
\hline & & Inflatable water toys & 1304 \\
\hline & & Skate boards & 1305 \\
\hline & & Snow boards & 1306 \\
\hline & & Slumber bags & 1307 \\
\hline & & Sports equipment & 1308 \\
\hline & & Vinyl pools & 1309 \\
\hline & & Water slides & 1310 \\
\hline & & Gloves & 1311 \\
\hline Stationary / Paper & 14 & Address books & 1401 \\
\hline
\end{tabular}




\begin{tabular}{|c|c|c|c|}
\hline & & Balloons & 1402 \\
\hline & & Bookmarks & 1403 \\
\hline & & Diaries & 1404 \\
\hline & & Greeting cards & 1405 \\
\hline & & Party goods & 1406 \\
\hline & & Stationery & 1407 \\
\hline & & $\begin{array}{c}\text { Desktop } \\
\text { accessories }\end{array}$ & 1408 \\
\hline Toys / Games / & 15 & Action figures & 1501 \\
\hline & & Activity sets & 1502 \\
\hline & & Arts and crafts sets & 1503 \\
\hline & & Beach toys & 1504 \\
\hline & & Board games & 1505 \\
\hline & & Card games & 1506 \\
\hline & & $\begin{array}{c}\text { Hobby sets and } \\
\text { supplies }\end{array}$ & 1507 \\
\hline & & $\begin{array}{l}\text { Dolls and } \\
\text { accessories }\end{array}$ & 1508 \\
\hline & & Models & 1509 \\
\hline & & Puzzles & 1510 \\
\hline
\end{tabular}




\begin{tabular}{|c|c|c|c|}
\hline & & $\begin{array}{c}\text { Remote controlled } \\
\text { toys }\end{array}$ & 1511 \\
\hline & & $\begin{array}{c}\text { Computer games } \\
\text { (CD-based, disc-based } \\
\text { and on-line) }\end{array}$ & 1512 \\
\hline & & Ride-ons & 1513 \\
\hline & & Videogames & 1514 \\
\hline Software / Website & 16 & $\begin{array}{c}\text { Educational } \\
\text { software }\end{array}$ & 1601 \\
\hline & & $\begin{array}{c}\text { Professional } \\
\text { software }\end{array}$ & 1602 \\
\hline & & $\begin{array}{l}\text { Reference } \\
\text { software }\end{array}$ & 1603 \\
\hline & & $\begin{array}{l}\text { Anti-virus } \\
\text { Software }\end{array}$ & 1604 \\
\hline & & Screen savers & 1605 \\
\hline & & Websites & 1606 \\
\hline Destinations & 17 & Stores & 1701 \\
\hline & & Malls & 1702 \\
\hline & & Restaurant & 1703 \\
\hline & & Cafes & 1704 \\
\hline
\end{tabular}




\begin{tabular}{|c|c|c|c|}
\hline & & $\begin{array}{c}\text { Other } \\
\text { Destinations }\end{array}$ & 1705 \\
\hline \multirow[t]{7}{*}{ Transportation } & 18 & Cars & 1801 \\
\hline & & Planes & 1802 \\
\hline & & Helicopters & 1803 \\
\hline & & Motorbikes & 1804 \\
\hline & & Railways & 1805 \\
\hline & & Bicycle & 1806 \\
\hline & & Water scooter & 1807 \\
\hline Cigarettes & 19 & & \\
\hline \multirow[t]{3}{*}{ Finance } & 20 & Banks & 2001 \\
\hline & & $\begin{array}{l}\text { Credit/Debit } \\
\text { Cards }\end{array}$ & 2002 \\
\hline & & Check & 2003 \\
\hline \multirow[t]{3}{*}{ Entertainment } & 21 & Cinema theaters & 2101 \\
\hline & & TV channels & 2102 \\
\hline & & Radio Channels & 210 \\
\hline \multirow[t]{2}{*}{ Tourist Destination } & 22 & Parks and Gardens & 2201 \\
\hline & & Buildings & 2202 \\
\hline $\begin{array}{l}\text { Construction Material } \\
\text { including Fixtures }\end{array}$ & 23 & Cement & 2301 \\
\hline
\end{tabular}




\begin{tabular}{|c|c|c|c|}
\hline & & Flooring & 2302 \\
\hline & & Fixtures & 2303 \\
\hline & & Metal & 2304 \\
\hline & & Heavy Equipment & 2305 \\
& & i.e. construction & \\
& & vehicles & \\
\hline
\end{tabular}

8. Overall duration of product placement - The overall duration of each product appearance will be recorded in terms of minutes and seconds. The entire duration of product placement will be calculated by adding the time duration of product visibility through different "shot angles," visibility in the "background and "foreground" of the scene, a "character's use of the entire product," or just a "part or function of the product.”

9. Duration of brand name appearance - The duration of the amount of time for which a brand name or logo is onscreen will be calculated under this variable.

10. Type of product placement - Each product appearing on screen will be assigned to one of the following categories of types of product placement.

\begin{tabular}{|c|c|}
\hline Category & Code \\
\hline Seen & 1 \\
\hline Mentioned & 2 \\
\hline Used & 3 \\
\hline
\end{tabular}


11. Primary association of a brand with a character - Each product appearing on screen will be analyzed for their primary association with a character in the movie.

\begin{tabular}{|c|c|}
\hline Category & Code \\
\hline With a star & 1 \\
\hline With a non-star & 2 \\
\hline With none of the characters & 3 \\
\hline
\end{tabular}

12. Theatrical context of a brand placement

\begin{tabular}{|c|c|}
\hline Category & Code \\
\hline Positive & 1 \\
\hline Negative & 2 \\
\hline Neutral & 3 \\
\hline
\end{tabular}

13. Integration into the storyline

\begin{tabular}{|c|c|}
\hline Category & Code \\
\hline Integrated & 1 \\
\hline Non-integrated & 2 \\
\hline
\end{tabular}

14. Level of product placement - Calculating the level of product placement is a twostep process. The first step is to calculate how many of the six characteristics of product placement are delivered by each placement. The second step is to 
calculate the level of product placement by analyzing how many characteristics are fulfilled by a particular product placement.

First Step:

a. Appropriateness of the product placement

\begin{tabular}{|c|c|}
\hline Category & Code \\
\hline Yes & 1 \\
\hline No & 2 \\
\hline
\end{tabular}

b. Impression

\begin{tabular}{|c|c|}
\hline Category & Code \\
\hline Yes & 1 \\
\hline No & 2 \\
\hline
\end{tabular}

c. Implied Endorsement

\begin{tabular}{|c|c|}
\hline Category & Code \\
\hline Yes & 1 \\
\hline No & 2 \\
\hline
\end{tabular}

d. Verbal Reference

\begin{tabular}{|c|c|}
\hline Category & Code \\
\hline Yes & 1 \\
\hline No & 2 \\
\hline
\end{tabular}


e. Brand Message

\begin{tabular}{|c|c|}
\hline Category & Code \\
\hline Yes & 1 \\
\hline No & 2 \\
\hline
\end{tabular}

f. Integration

\begin{tabular}{|c|c|}
\hline Category & Code \\
\hline Yes & 1 \\
\hline No & 2 \\
\hline
\end{tabular}

Second Step:

Level of product placement

\begin{tabular}{|c|c|}
\hline Category & Code \\
\hline Level A & 1 \\
\hline Level B & 2 \\
\hline Level C & 3 \\
\hline
\end{tabular}

